\title{
Utilizing MIKC-type MADS-box protein SOC1 for yield potential enhancement in maize
}

\author{
Guo-qing Song ${ }^{1}$ (D) Xue Han ${ }^{1} \cdot$ John T. Ryner ${ }^{1} \cdot$ Addie Thompson $^{2} \cdot$ Kan Wang $^{3}$
}

Received: 2 March 2021 / Accepted: 25 May 2021 / Published online: 6 June 2021

(c) The Author(s) 2021

\begin{abstract}
Key message Overexpression of Zea mays SOC gene promotes flowering, reduces plant height, and leads to no reduction in grain production per plant, suggesting enhanced yield potential, at least, through increasing planting density. Abstract MIKC-type MADS-box gene SUPPRESSOR OF OVEREXPRESSION OF CONSTANS 1 (SOC1) is an integrator conserved in the plant flowering pathway. In this study, the maize SOCl ( $\mathrm{FSOC1}$ ) gene was cloned and overexpressed in transgenic maize $\mathrm{Hi}-\mathrm{II}$ genotype. The $\mathrm{T}_{0}$ plants were backcrossed with nontransgenic inbred $\mathrm{B} 73$ to produce first generation backcross $\left(\mathrm{BC}_{1}\right)$ seeds. Phenotyping of both transgenic and null segregant $(\mathrm{NT}) \mathrm{BC}_{1}$ plants was conducted in three independent experiments. The $\mathrm{BC}_{1}$ transgenic plants showed new attributes such as increased vegetative growth, accelerated flowering time, reduced overall plant height, and increased grain weight. Second generation backcross $\left(\mathrm{BC}_{2}\right)$ plants were evaluated in the field using two planting densities. Compared to $\mathrm{BC}_{2} \mathrm{NT}$ plants, $\mathrm{BC}_{2}$ transgenic plants, were $12-18 \%$ shorter, flowered 5 days earlier, and showed no reduction in grain production per plant and an increase in fat, starch, and simple sugars in the grain. Transcriptome comparison in young leaves of 56-day-old $\mathrm{BC}_{1}$ plants revealed that the overexpressed $\mathrm{ZmSOC1}$ resulted in 107 differentially expressed genes. The upregulated transcription factor DNA BINDING WITH ONE FINGER 5.4 (DOF5.4) was among the genes responsible for the reduced plant height. Modulating expression of SOC1 opens a new and effective approach to promote flowering and reduce plant height, which may have potential to enhance crop yield and improve grain quality.
\end{abstract}

Keywords Dwarf plant · Flowering · SUPPRESSOR OF OVEREXPRESSION OF CONSTANS $1 \cdot$ Zea mays

\section{Introduction}

Increasing crop production is key to feeding the future (Ash et al. 2010). Breeding efforts in both public and private sectors in agriculture have been made to increase yield through genetic manipulation of various traits such as biotic or abiotic stress resistance (Nelson et al. 2007; Tester and

Communicated by Leandro Peña.

Guo-qing Song

songg@msu.edu

1 Department of Horticulture, Plant Biotechnology Resource and Outreach Center, Michigan State University, East Lansing, MI 48824, USA

2 Department of Plant Soil and Microbial Sciences, Michigan State University, East Lansing, MI 48824, USA

3 Department of Agronomy, Crop Bioengineering Center, Iowa State University, Ames, IA 50011-1051, USA
Langridge 2010). Of the proposed flowering pathway gene networks (Fornara et al. 2010; Hill and Li 2016), MADS-box genes play significant roles in the formation of floral meristem and floral organs (e.g., male and female gametophyte), the control of floral transition and flowering time, and the development of seed and fruit (Becker and Theissen 2003; Causier et al. 2002; Garcia-Marotoet al. 2003; Gramzow and Theissen 2010, 2013; Heijmans et al. 2012; Masiero et al. 2011; Ng and Yanofsky 2001; Parenicova et al. 2003; Theissen et al. 2000). In addition, MADS-box genes function in root growth, lateral root formation, and morphogenesis of other organs (Smaczniak et al. 2012; Tapia-Lopezet al. 2008; Teo et al. 2019; Yu et al. 2014; Zhang and Forde 1998). Manipulation of these MADS-box genes provides an alternative approach to modulating plant reproductive growth, with the potential to influence crop yield (Castelan-Munoz et al. 2019; Hill and Li 2016; Trevaskis 2018).

MADS-domain proteins differ in the domain following the C-terminus of the MADS-box (Gramzow and Theissen 
2010; Heijmans et al. 2012; Masiero et al. 2011). Type-I MADS-box genes usually have a single exon and are further divided into three subfamilies, $\mathrm{M} \alpha, \mathrm{M} \beta$, and $\mathrm{M} \gamma$. Type-I MADS-domain proteins function in female gametophyte, embryo, and endosperm development, respectively (Masiero et al. 2011; Parenicova et al. 2003). Type-II MADS proteins are plant-specific MIKC proteins that have conserved MADS (M-), intervening (I-), keratin-like (K-), and C-terminal (C-) domains (Theissen et al. 1996). The MIKC proteins consist of MIKC* and MIKC $^{\mathrm{c}}$ (classical MIKC) subgroups and are key regulators in plant reproductive processes (Adamczyk and Fernandez 2009; Dreni and Kater 2014; Dreni and Zhang 2016; Gramzow and Theissen 2015; Liu et al. 2013; Smaczniak et al. 2012; Verelst et al. 2007). For example, six MIKC*-type genes [AGAMOUS-LIKE 30 (AGL30), AGL65, AGL66, AGL67, AGL94, and AGL104] playing a significant role in regulating pollen development have been identified in Arabidopsis thaliana (Kwantes et al. 2012; Liu et al. 2013; Verelst et al. 2007). The MIKC ${ }^{\mathrm{c}}$ genes are divided into 13 major gene clades that play specific roles in the $\mathrm{ABC}$ model of floral development and in timing plant flowering (Amasino 2010; Heijmans et al. 2012; Lee and Lee 2010; Smaczniak et al. 2012; Wellmer and Riechmann 2010). Of the MIKC $^{\mathrm{c}}$ gene clades, SUPPRESSOR of OVEREXPRESSION OF CONSTANS 1 (SOC1) and SOC1-like genes in the TM3/ SOC1 clade are major flowering pathway integrators that harmonize flowering signals from multiple pathways (Alter et al. 2016; Lee and Lee 2010; Pin et al. 2010; Wellmer and Riechmann 2010). Modulating expression of SOCl can change the overall process of floral induction and flowering control, thus affecting crop yield.

Due to their significance in plant development (Gramzow and Theissen 2010; Schilling et al. 2018), several MADSbox genes have been patented for their regulatory roles in enhancing agronomic traits (Bae et al. 2011; Cacharron et al. 2000; Danilevskaya and Bruce 2008; Giovannoni et al. 2013; Podila et al. 2005; Takatsuji and Kapoor 2002), of which a maize ZMM28 MADS-box gene (patent application \# WO2008148872A1) has been patented for yield increase through its overexpression (Danilevskaya and Bruce 2008). The ZMM28 gene is a homolog of the Arabidopsis FRUITFUL (FUL)/ AGAMOUS-like 8 (AGL8) gene, and it regulates maize flowering (Munsteret al. 2002). Increasing the expression of the $Z M M 28$ gene enhanced grain yield in the field (Wu et al. 2019). In 2019, USDA APHIS released a petition from DU PONT Pioneer Hi-Bred for determination of nonregulated status for enhanced grain yield potential and glufosinate-ammonium resistant DP202216 maize after safety evaluation of the maize ZMM28 protein (Anderson et al. 2019a, b; Catron 2019).

The SOC1 protein is a MIKC protein. In Arabidopsis, the $S O C 1$ gene is a positive regulator of the downstream MADSbox genes such as APETALAl (API) and FUL/AGL8 (Lee and Lee 2010). Maize (Zea mays) SOC1 gene (ZmSOC1 or ZmMADS1) is a flowering activator (Alter et al. 2016). The effect of overexpression of the $\mathrm{ZmSOCl}$ on maize grain production has not been reported. In this report, we describe the potential of using the $\mathrm{ZmSOCl}$ to enhance maize grain yield. We present phenotypic data of the first $\left(\mathrm{BC}_{1}\right)$ and second $\left(\mathrm{BC}_{2}\right)$ generations of backcross $(\mathrm{BC})$ plants. These data provide evidence that the constitutive expression of ZmSOCl can result in enhanced yield potential through (1) hastening plant growth, (2) promoting flowering, (3) reducing overall plant height, (4) shortening overall time (about 2 weeks) needed from sowing to harvest, and (5) increasing or having no reduction in grain weight per plant. We also provide RNA-seq data derived from young leaves of six transgenic and three nontransgenic $\mathrm{BC}_{1}$ lines to reveal the overall impact of $\mathrm{ZmSOCl}$ overexpression on expression of other associated genes.

\section{Materials and methods}

\section{Constructs and plant transformation}

Seeds of maize inbred line B104 were germinated to grow to 2-week old plants to harvest leaves. Isolation of total RNA was conducted using the RNeasy Mini Kit (Qiagen, Valencia, CA, USA). The RNA sample was treated by DNase. Reverse transcription of RNA to cDNA was performed using SuperScript II reverse transcriptase (Invitrogen, Carlsbad, CA, USA).

Sequence of the maize SOC1 gene (ZmSOCl or ZmMADS1) has been published in GenBank (accession number: NM_001111682.1) (Alter et al. 2016). The $\mathrm{ZmSOCl}$ sequence is also available in GenBank (accession number: HQ858775.1). Two pairs of polymerase chain reaction (PCR) primers included in Table S1 were designed to amplify the $\mathrm{ZmSOCl}$ from the cDNA of the leaf tissues of maize inbred line B104. The first pair of primers, MK_F and MK_R, were used to amplify the exact coding region of ZmSOC1. Using the second pair of primers, MK_F1_Kpn I and MK_R1_Xba I, unique restriction enzymes Kpn I and $X b a$ I were added to the 5'- and $3^{\prime}$-end of the ZmSOCl, respectively. The PCR products were double digested using $K p n$ I and $X b a$ I. Meanwhile, the pKANNIBAL plasmid was digested using $K p n$ I and $X b a$ I to remove the PDK intron. The digested PCR products and the pKANNIBAL without the intron were ligated to insert the $\mathrm{ZmSOCl}$ gene between the CaMV 35S promoter and the Ocs terminator (Fig. S1). The ligated pKANNIBAL-ZmSOC1 plasmid was digested using Not I to release the CaMV 35S-ZmSOC1Ocs expression cassette. The released cassette was blunted using Klenow enzyme. Binary vector pTF101.1 (Paz et al. 2004) was double digested by Hind III and EcoR I, and the sticky ends of the digested pTF101.1 plasmid were blunted 
using Klenow enzyme. The blunt end pTF101.1 fragment and the blunt end CaMV 35S-ZmSOC1-Ocs expression cassette were ligated to generate pTF101.1-ZmSOC1 for overexpression of the ZmSOCl (herein ZmSOCl-OX) (Fig. S1). The pTF101.1-ZmSOCl contains the bialaphos resistance (bar) gene under the CaMV 35S promoter for selection of transformed plant cells using glufosinate (GS) herbicide. The $\mathrm{ZmSOCl}$ in the resulting pTF101.1-ZmSOC1 were sequenced. Sanger sequencing data confirmed that a 696bp $\mathrm{ZmSOC1}$ derived from the cDNA of the maize inbred line B104 was successfully inserted into the binary vector pTF101.1-ZmSOC1. In the 696-bp ZmSOC1 sequence, $694 \mathrm{bp}$ are identical to the published 696-bp reference deposited in the GenBank (accession numbers HQ858775.1 and NM_001111682.1). The protein sequence of the cloned $\mathrm{ZmSOCl}$ is identical to that derived either from the HQ858775.1 or from a part of the NM_001111682.1. The pTF101.1-ZmSOCl verified through sequencing was used for maize transformation (Fig. S1).

The pTF101.1-ZmSOC1 was transformed into Agrobacterium tumefaciens strain EHA101. The construct was introduced into maize using Agrobacterium-mediated immature embryo infection method of Hi-II (A188 × B73) genotype (Frame et al. 2015). The $\mathrm{T}_{0}$ transgenic Hi-II plants were backcrossed with nontransgenic inbred line $\mathrm{B} 73$ to produce first generation of backcross $\left(\mathrm{BC}_{1}\right)$ seeds, which have about $75 \%$ of the $\mathrm{B} 73$ genetic background.

\section{Phenotyping of the $B C_{1}$ plants grown in pots}

In each experiment, ten $\mathrm{BC}_{1}$ lines, each having more than one hundred seeds, were used for phenotyping in this study. $\mathrm{BC}_{1}$ seeds were germinated in water-soaked Suremix Perlite planting medium (Michigan Grower Products Inc., Galesburg, MI) in 4-inch plastic pots $(8.9 \mathrm{~cm}$ width $\times 12.7 \mathrm{~cm}$ height) in a greenhouse in the springs of 2018 and 2019. Three experiments were conducted, including two in 2018 and one in 2019. Ten seeds per selected line for each experiment were sowed on May 17 and June 11 in 2018 and 16 seeds per line were sowed on May 11 in 2019. In each experiment, poor germinating lines with less than two plants were excluded for further phenotypic data collection in this study. Individual $\mathrm{BC}_{1}$ plants were transplanted to a 4-gallon pot (top diameter $30 \mathrm{~cm}$, bottom diameter $24 \mathrm{~cm}$, depth $27 \mathrm{~cm}$ ) and the plants were grown in a secured courtyard under natural environmental conditions at Michigan State University, East Lansing, Michigan (latitude 42.701847, longitude -84.482170). All of the plants were irrigated every other day and fertilized once a week using fertilizer $(\mathrm{N}: \mathrm{P}: \mathrm{K}=20: 20: 20)$. Young leaves of 30 to 40 -day old plants, $0.5 \mathrm{~g}$ per plant, were collected separately for DNA isolation, frozen in liquid nitrogen, and stored in a freezer at $-80{ }^{\circ} \mathrm{C}$.
Phenotypic data collection included plant height, seed germination date, date of tassel appearance, date of silk appearance, the total number of stem nodes and leaves, the number of cobs, dry weight of aerial parts without ears, dry weight of ear(s) excluding husk(s), and dry weight of grain. Plant heights measured during plant growth refer to stalk heights from the soil surface to the node of the highest leaf. The final heights of the maize plants refer to stalk heights from the soil surface to the top of tassels at harvest time. All of the plants for each experiment were harvested at the same time after they reached full physiological maturity in late October. The aerial parts of each plant were collected in a paper bag and dried at $25^{\circ} \mathrm{C}$ for over 2 months in the lab prior to weighing the dry weights of total aerial parts, cob(s), and grain. For the third experiment in 2019, the date that an ear reached mature color (Fig. S2) was recorded for each plant. To reduce bias during data collection, identification of transgenic and nontransgenic plants using PCR was mostly performed about 1 month before plant harvesting. In total, plants from nine transgenic lines in three experiments were used for phenotypic data collection.

\section{Field test of $\mathrm{BC}_{2}$ plants}

$\mathrm{BC}_{1}$ seeds of transgenic lines $\mathrm{c} 7$ and $\mathrm{c} 9$ were sown in a greenhouse with temperatures above $21^{\circ} \mathrm{C}$ and a 16-h photoperiod. For further seed production, B73 was used as the pollinator. Ten seeds for each of the B73, c7, and c9 were sown at one time for four times at 5-day intervals to make sure the flowering time of B73 was able to meet that of the $\mathrm{c} 7$ and $\mathrm{c} 9$. The presence/absence of the transgene in the seedlings was determined using PCR. Flowering time for all plants was recorded. All tassels of $\mathrm{BC}_{1}$ plants were removed. Pollen from the B73 plants was used to pollinate the transgenic plants. The ears of transgenic plants were covered using pollinating bags. $\mathrm{BC}_{2}$ seeds from each individual plant were harvested separately.

$\mathrm{BC}_{2}$ seeds from three $\mathrm{c} 7$ lines and three $\mathrm{c} 9$ lines were grown in the field. For each line, 30 plants were randomly grown in each of the six plots, including three plots at a high planting density of 40,000 plants/acre and another three at a low planting density of 32,000 plants/acre. Two extra rows of B73 plants for each plot were used as protective borders. A drip irrigation system was installed in the field for plant irrigation as needed. Phenotypic data collection, including flowering time, plant height, leaf number, ear dry weight, and grain dry weight, were conducted using the same procedures described above for the $\mathrm{BC}_{1}$ plants. In addition, grain quality from 50 plants were measured using a Grain Analyser (Infratec ${ }^{\mathrm{TM}}$ 1241, FOSS Analytical AB, Denmark). 


\section{Detection of the transgenic plants}

DNA was isolated from about $200 \mathrm{mg}$ of leaf tissue for each sample using the cetyltrimethylammonium bromide (CTAB) method (Doyle and Doyle 1987). Maize Actin gene primers ZmAct_F and ZmAct_R were used as a control to verify the template DNA. Two pairs of primers, bar-F and bar-R for the bar gene, $35 \mathrm{~S}-\mathrm{F}$ (3' portion of the CaMV $35 \mathrm{~S}$ promoter) and MK_R for the ZmSOCl gene (Table S1), were used to detect the presence of transgenes in each sample. PCR reaction conditions for all primer pairs started with an initial denaturation for two min at $94{ }^{\circ} \mathrm{C}, 30$ cycles of $45 \mathrm{~s}$ at $94{ }^{\circ} \mathrm{C}, 60 \mathrm{~s}$ at $58{ }^{\circ} \mathrm{C}$ and $90 \mathrm{~s}$ at $72{ }^{\circ} \mathrm{C}$, and a final extension for $10 \mathrm{~min}$ at $72{ }^{\circ} \mathrm{C}$. All amplified PCR products were separated on $1 \%$ agarose gel containing ethidium bromide and visualized and photographed under UV light (Fig. S3).

\section{RNA sequencing and transcriptome analysis}

For RNA isolation, leaves from 56-day-old plants at a vegetative growth stage were harvested (Fig. S2), frozen immediately in liquid nitrogen, and stored at $-80{ }^{\circ} \mathrm{C}$ in a freezer. Two transgenic lines, $c 7$ and c9, were used. A total of nine samples from nine plants were used, including three transgenic and three nontransgenic null segregants from the $\mathrm{c} 7$ transgenic event and 3 transgenic plants from the $\mathrm{c} 9$ transgenic event. Total RNA of each sample was isolated from about $500 \mathrm{mg}$ of young leaf tissue using a separate CTAB method (Zamboni et al. 2008) and purified using RNeasy Mini Kit (Qiagen, Valencia, CA, USA). On-Column DNase digestion with the RNase-free DNase Set was used to remove DNA in the RNA samples (Qiagen). RNA quality was determined using the High Sensitivity RNA ScreenTape system (Agilent technologies, Santa Clara, CA). All of the RNA samples used for RNA sequencing had a quality score greater than 5.0, and cDNA of all these samples were synthesized for reverse-transcription of 3-5 $\mu \mathrm{g}$ RNA per sample using SuperScript II reverse transcriptase (Invitrogen, Carlsbad, CA, USA). Regular RT-PCR was used to verify the expression of the transgenes before RNA sequencing. The reaction conditions for RT-PCR were $94{ }^{\circ} \mathrm{C}$ for $2 \mathrm{~min}$, 35 cycles of $45 \mathrm{~s}$ at $94{ }^{\circ} \mathrm{C}, 60 \mathrm{~s}$ at $62{ }^{\circ} \mathrm{C}$ and $60 \mathrm{~s}$ at $72{ }^{\circ} \mathrm{C}$, with a final $10 \mathrm{~min}$ extension at $72{ }^{\circ} \mathrm{C}$. RT-PCR products were separated and visualized on $1.0 \%$ agarose gel containing ethidium bromide.

The RNA samples were sequenced (150 bp-paired end reads) using the Illumina HiSeq4000. All sequencing was performed at the Research Technology Support Facility at Michigan State University (East Lansing, Michigan, USA). The FastQC program (www.bioinformatics.babra ham.ac.uk/projects/fastqc/) was used to assess the quality of sequencing reads for the per base quality scores. About 32-42 million reads (MR) for each of the nine biological samples with average scores ranging from 37 to 40 were obtained for transcriptome analysis. The paired-end reads ( 100 MR in total) combined from one sample of the NT line and one sample for each of the two TR lines were used for transcriptome assembly to develop a maize transcriptome reference ZmTrinity using Trinity/2.8.5 (Haas et al. 2013). This transcriptome reference was anticipated to cover all potential isoforms in the sequence reads. The RNA-seq reads of three biological replicates for each of the $\mathrm{c} 7$ and $\mathrm{c} 9$ transgenic lines and one $\mathrm{c} 7$ line were analyzed. The paired reads were aligned to the transcriptome reference ZmTrinity, and the abundance for each of a single read was estimated using the Trinity command "align_and_estimate_abundance. pl". The Trinity command "run_DE_analysis.pl-method edgeR" was used to conduct differential expression analysis (Haas et al. 2013). Differentially expressed transcripts (DETs) with a false discovery rate (FDR) value below 0.05 ( $p$ value $<0.001$ ) were used for further analysis of different pathway genes of maize.

Pathway genes of nine phytohormones in Arabidopsis, including auxin, cytokinin, ABA, ethylene, gibberellin, brassinosteroid, jasmonic acid, salicylic acid, and strigolactones, were retrieved from RIKEN Plant Hormone Research Network (http://hormones.psc.riken.jp/). Similarly, pathway genes of sugar in Arabidopsis were identified. These Arabidopsis hormones, MADS-box, and sugar genes (Table S2) were used as queries to blast against the transcriptome reference ZmTrinity and the isoforms showing $e$ values less than -20 were identified and used for transcriptome comparisons. Flowering pathway genes in Arabidopsis and cereals (Walworth et al. 2016) were used to analyze flowering-related DETs identified in this study. Cytoscape 3.8.2 was used to construct gene networks of overrepresented gene ontology (GO) terms for the selected DETs under BiNGO's default parameters with selected ontology file 'GOSlim_Plants' or 'GO_Full' and selected organism 'A. thaliana' (Maere et al. 2005; Shannon et al. 2003). Most of the analyses were performed using the resources at the High Performance Computing Center at Michigan State University.

Quantitative RT-PCR (RT-qPCR) using SYBR Green system (LifeTechnologies, Carlsbad, CA) were conducted to check the selected transcripts. The primers were designed according to the RNA-seq data, and ZmActin 1 was used to normalize the RT-qPCR results (Table S1). RT-qPCR was performed on a Roche LightCycler ${ }^{\circledR} 480$ Instrument II. The reaction conditions for RT-qPCR were $95{ }^{\circ} \mathrm{C}$ for $5 \mathrm{~min}, 45$ cycles of $30 \mathrm{~s}$ at $95{ }^{\circ} \mathrm{C}, 45 \mathrm{~s}$ at $62{ }^{\circ} \mathrm{C}$ and $30 \mathrm{~s}$ at $72{ }^{\circ} \mathrm{C}$. Transcript levels within samples were normalized to Actin. Foldchanges were calculated using $2^{-\Delta \Delta \mathrm{Ct}}$, where $\Delta \Delta \mathrm{Ct}=\left(\mathrm{Ct}_{\mathrm{TARGET}}-\mathrm{Ct}_{\mathrm{NOM}}\right)_{\text {transgenic }}$ - $\left(\mathrm{Ct}_{\text {TARGET }}-\mathrm{Ct}_{\text {NOM }}\right)_{\text {nontransgenic }}$. Three biological samples and three technical replicates were used for the analysis of each transgenic and nontransgenic line. 


\section{Statistical analysis}

Statistical analysis of the phenotypic data was conducted using ANOVA and TukeyHSD in RStudio (Version 1.0.136).

\section{Results}

\section{The overexpressed ZmSOC1 causes phenotypic changes}

Inbred maize genotypes remain recalcitrant for genetic transformation (Yadava et al. 2016). In this study, we performed transgene analysis in a transformable Hi-II genotype, which has a hybrid genetic background of A188 and B73 (Frame et al. 2015). To produce seeds, $T_{0}$ transgenic plants were pollinated with nontransgenic inbred $\mathrm{B} 73$ to obtain $\mathrm{BC}_{1}$ seeds. A total of 16 independent $\mathrm{ZmSOCl}$ overexpression events were brought to maturity. $\mathrm{BC}_{1}$ and $\mathrm{BC}_{2}$ seeds should have $~ 75$ and $87.5 \%$ of $\mathrm{B} 73$ genetic background, respectively. Because of the complex hybrid background, each of the $\mathrm{BC}_{1}$ and $\mathrm{BC}_{2}$ plants of $\mathrm{Hi}$-II was not genetically identical. To evaluate the effect of the ZmSOCl transgene in diverse genetic backgrounds, nontransgenic, null segregant plants from nine independent $\mathrm{BC}_{1}$ lines were identified and used as negative controls in the $\mathrm{BC}_{1}$ experiments. These null segregants (NT) shared the similar genetic background as well as the tissue culture effects with the transgenic counterparts (TR) because they were derived from the same ears. For the field test of the $\mathrm{BC}_{2}$ plants, six lines were derived from two $\mathrm{BC}_{1}$ lines (c7 and $\mathrm{c} 9$ ), for which RNA-seq was conducted.

Three $\mathrm{BC}_{1}$ experiments under three environmental conditions were conducted in two summers to evaluate the impact of ZmSOCl-OX on the following physiological or agronomic traits: (1) seed germination time, (2) time of tassel appearance, (3) time of silk appearance, (4) days between tassel and silk appearance, (5) leaf number, (6) plant height, (7) dry weight (plant aerial material excluding ears), (8) dry weight (ear), and (9) dry weight (grain). These selected physiological or agronomic traits are important criteria to evaluate yield potential. Of the nine traits analyzed (Table 1, Table S3), germination time of the TR seeds $(5.3 \pm 1.7$ days) was similar to that of the NR seeds ( $5.1 \pm 9.5$ days); this was the only unchanged trait observed consistently in all three experiments. Two lines, c7 and c9, which had higher numbers of both TR and NT plants (Table S3), were selected for a detailed phenotypic and transcriptomic analysis. For the field test of the $1080 \mathrm{BC}_{2}$ plants, the results confirmed the accelerated flowering and reduced plant stature in the TR plants. In addition, the $\mathrm{BC}_{2}$ TR plants showed unreduced grain production per plant and increased contents of starch, fat, and

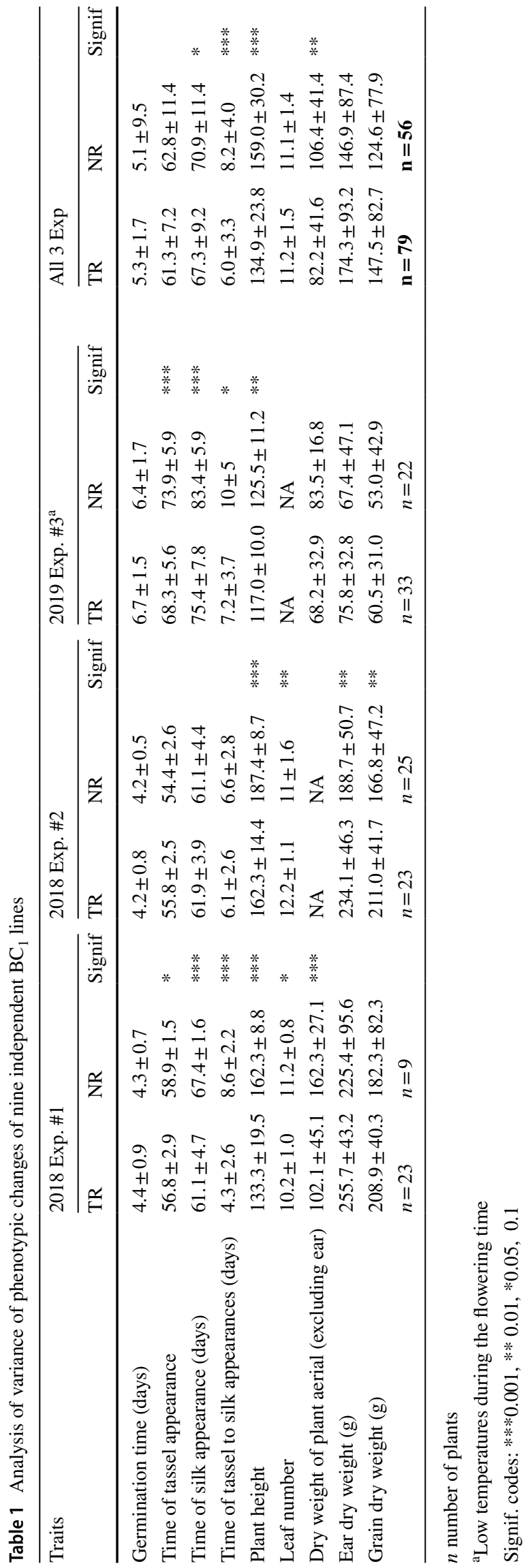


simple sugars in the grain. These phenotypic changes, as well as the ZmSOC1-OX-induced differentially expressed genes (DEGs), provide encouraging data that implicate the potential of utilizing the $\mathrm{ZmSOCl}$-OX gene to increase maize yield.

\section{Overexpression of ZmSOC1 promotes flowering}

ZmSOC1-OX resulted in early flowering in both $\mathrm{BC}_{1}$ and $\mathrm{BC}_{2}$ plants. Upon close examination of $\mathrm{BC}_{1} \mathrm{TR}$ and $\mathrm{NT}$ plants, we observed that the TR plants were taller than the NT plants before flowering in the first two experiments, but ended up shorter than the NT plants when they reached maturity (Table 1 ). For the $\mathrm{BC}_{1}$ lines tested in experiment $\# 1$ and \#2 in 2018, the seeds were sown in mid-May and mid-June, respectively. To verify the observation, a third experiment was conducted in the summer of 2019. Seeds for experiment \#3 were sown in mid-May, similar to experiment $\# 1$. We measured the heights of all plants from nine independent $\mathrm{BC}_{1}$ lines every 10 days from the $20^{\text {th }}$ to the $90^{\text {th }}$ day after sowing. The comparisons again showed that TR plants were taller than NT plants during the vegetative growth period (between 20 and 70 days after sowing) (Fig. 1A). After around day 70, NT plants grew taller, and mature TR plants were shorter than NT plants in the end (Table 1).

For the $\mathrm{BC}_{1}$ plants, slightly accelerated flowering, indicated by the time of tassel and silk appearance, was observed in TR plants in two of the three experiments. Tassels appeared 1 day earlier for TR $(61.3 \pm 7.2$ days $)$ than NT (62.8 \pm 11.4 days) with no significant difference (Fig. 2A). Silks appeared three days earlier for TR $(67.3 \pm 9.2$ days $)$ than NT $(70.9 \pm 11.4$ days $)$ with a significance value of $p=0.05$ (Fig. 2B). In addition, the time from the appearance of tassels to the appearance of silks was about two days shorter for the TR plants $(6.0 \pm 3.3$ days $)$ than that of the NT plants $(8.2 \pm 4.0$ days $)$ in all three experiments, which is highly significant $(p=0.001)$. The reduced nicking time between male and female flowers can facilitate an effective pollination that affects grain production. We also made backcrosses between $\mathrm{B} 73$ and TR plants to produce $\mathrm{BC}_{2}$ seeds for $\mathrm{c} 7$ and $\mathrm{c} 9$. All of the $\mathrm{BC}_{1}$ TR plants flowered 5-10 days earlier than the $\mathrm{BC}_{1} \mathrm{NR}$ and $\mathrm{B} 73$ plants in the greenhouse. For the field test of the $\mathrm{BC}_{2}$ plants, dynamic changes of plant height at early plant growth stages were not measured. Regardless of the planting densities, early flowering ( $\sim 5$ days for the appearance of both tassels and silks) was observed for the TR plants (Figs. 1B, 2C). Overall, overexpression of $\mathrm{ZmSOCl}$ was able to promote flowering. The early flowering of $\mathrm{ZmSOC1-OX}$ plants grown under natural conditions either in pots for the $\mathrm{BC}_{1}$ or in the field for the $\mathrm{BC}_{2}$ TR plants is consistent with the results observed in the greenhouse-grown ZmSOC1-OX plants (Alter et al. 2016).
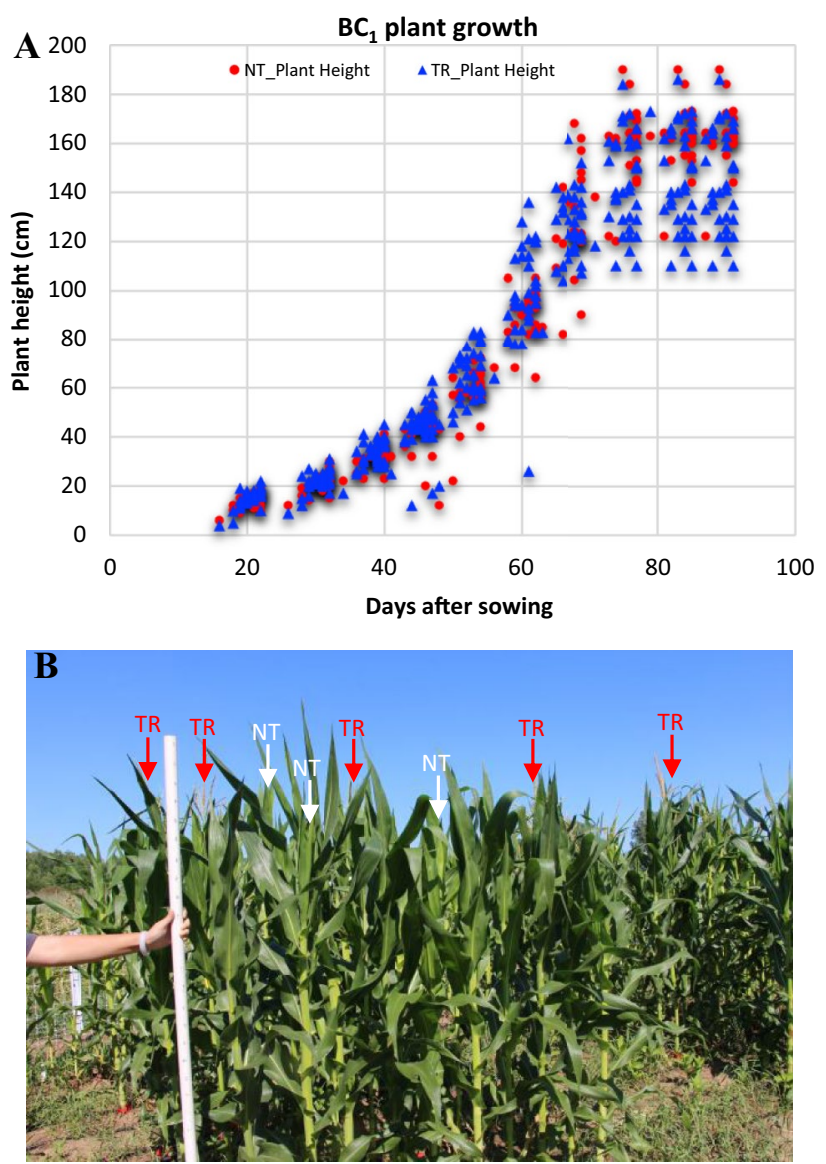

Fig. 1 Growth of transgenic ZmSOC1-OX (TR) and null segregant (NT) maize plants of $\mathrm{BC}_{1}$ and $\mathrm{BC}_{2}$ lines. $\mathrm{A}$ Data from nine $\mathrm{BC}_{1}$ lines in experiment \#3. $\mathbf{B}$ 60-day-old $\mathrm{BC}_{2}$ plants planted in a low-density field plot. Transgenic and nontransgenic plants were randomly grown in each plot

\section{Overexpression of $\mathrm{ZmSOC1}$ reduces plant height}

Plant height of TR plants was significantly reduced (Fig. 3A, $3 \mathrm{~B}$, Table 1 , Table $\mathrm{S} 3$ ). For mature $\mathrm{BC}_{1}$ plants, the average height from soil to tassels was $134.9 \pm 23.8 \mathrm{~cm}$ for TR plants but $159 \pm 30.2$ for NT ( $p=0.001)$ (Fig. 3A). For $\mathrm{BC}_{2}$ plants, the height of TR plants was shorter than NT plants at the time of both tassel appearance (TR $117.4 \pm 26.9 \mathrm{~cm}$ vs. NT $140.0 \pm 25.7 \mathrm{~cm}$ ) and maturity (TR $152.3 \pm 27.5 \mathrm{~cm}$ vs. NT $171.2 \pm 28.1 \mathrm{~cm})$ (Fig. 3B).

For leaf number in the $\mathrm{BC}_{1}$ TR plants, a significant decrease and a significant increase were observed in experiment \#1 and experiment \#2, respectively (Table 1). For the $\mathrm{c} 7$ and $\mathrm{c} 9$ lines, TR plants had 1 and 1.4 fewer leaves than NT plants, respectively, in experiment \#1 (seed sown in mid-May 2018; Fig. 2B). In contrast, TR plants showed 1.8 and 2 more leaves than the NT plants, respectively, in experiment \#2 (seed sown in mid-June 2018). The inconsistency is likely due to the planting times that caused 


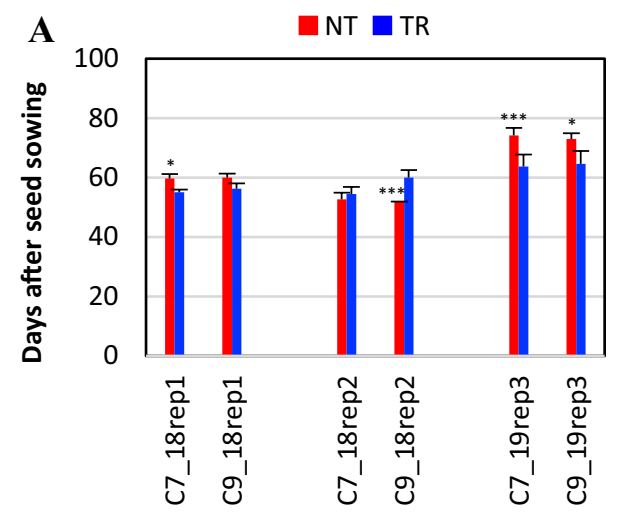

B
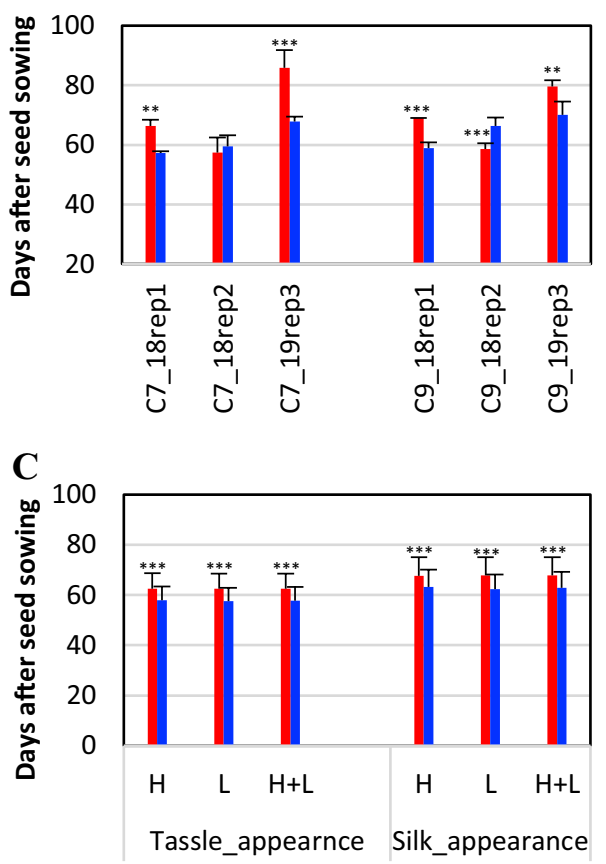

Fig. 2 Flowering time of transgenic ZmSOC1-OX (TR) and null segregant (NT) maize plants of $\mathrm{BC}_{1}$ and $\mathrm{BC}_{2}$ lines. The $\mathrm{BC}_{1}$ plants were from two independent $\mathrm{BC}_{1}$ lines (c7 and $\mathrm{c} 9$ ). Rep1, rep2, and rep3 represent experiment \#1, \#2 and \#3. A Tassel appearance time of $\mathrm{BC}_{1}$ lines. B Silk formation time of $\mathrm{BC}_{1}$ lines. Star(s) on each bar represent the comparison result between the TR and the NT plants of the same $\mathrm{BC}_{1}$ line in the same experiment, $\mathrm{n}$ for $\mathrm{c} 7 \_18 \mathrm{rep} 1 \mathrm{NT}=3$, $\mathrm{n}$ for c7_18rep1 TR=3, $\mathrm{n}$ for c7_18rep2 $\mathrm{NT}=4$, $\mathrm{n}$ for c7_18rep2 $\mathrm{TR}=4$, $\mathrm{n}$ for c7_17rep3 $\mathrm{NT}=8$, n for c7_19rep3 TR=6, n for c9_18rep1 $\mathrm{NT}=2, \mathrm{n}$ for c9_18rep1 $\mathrm{TR}=5$, $\mathrm{n}$ for $\mathrm{c} 9 \_18 \mathrm{rep} 2 \mathrm{NT}=5, \mathrm{n}$ for c9_18rep2 TR=3, n for c9_19rep3 $\mathrm{NT}=3$, n for c9_19rep3 TR $=8$. $\mathrm{C}$ Tassel and silk appearance time of $\mathrm{BC}_{2}$ lines. $\mathrm{BC}_{2}$ seeds from three c7 lines and three c9 lines were grown in a field. For each line, 30 plants were randomly grown in each of the six plots, including three plots for a high planting density of 40,000 plants/acre $(H)$ and another three for a low planting density of 32,000 plants/acre $(L)$. Star(s) on each bar represent the comparison result between the TR and the NT plants of the same planting density. Bars indicate standard deviation. Significance codes: $* * *<0.001, * *<0.01, *<0.05$ variations in the plant growth conditions under natural environmental conditions. Consequently, the averages of the leaf numbers for $\mathrm{BC}_{1}$ plants in two experiments were similar for both TR $(11.2 \pm 1.5$ leaves $)$ and NT $(11.1 \pm 1.4$ leaves) plants (Fig. 3C). For the $\mathrm{BC}_{2}$ plants, the leaf number of TR plants (11.4 \pm 1.7 leaves) was less than the NT plants $(12.9 \pm 1.9$ leaves) (Fig. 3D). Overall, it was reasonable to conclude that overexpression of the ZmSOC1 reduces leaf number because of the larger population of the $\mathrm{BC}_{2}$ plants. The results of both reduced plant height and leaf number in the $\mathrm{BC}_{2} \mathrm{TR}$ plants grown under the natural conditions are consistent with those reported in the greenhouse-grown $\mathrm{BC}_{1}$ plants (Alter et al. 2016).

\section{Overexpression of $\mathrm{ZmSOC} 1$ increases grain dry weight per plant}

Yield potential of the $\mathrm{ZmSOCl-OX}$ plants was not reported (Alter et al. 2016). For the $\mathrm{BC}_{1}$ plants, the increased dry weight for both ear and grain was recorded in TR plants in all three experiments, with significant difference in one experiment (Table 1, Table S3). Average dry weight of ear was over $27 \mathrm{~g}$ heavier for TR plants $(174.3 \pm 93.2 \mathrm{~g})$ when compared to NT plants $(146.9 \pm 87.4 \mathrm{~g})$. A nearly $23 \mathrm{~g}$ increase in average grain weight in TR plants $(147.5 \pm 82.7 \mathrm{~g})$ versus NT plants $(124.6 \pm 77.9 \mathrm{~g})$ was observed. For the $\mathrm{c} 7$ line, the grain dry weight of the TR plants showed a slight increase in experiment \#1 and \#3 and a significant increase in experiment $\# 2$ (Figs. 2F, 3, Fig. S2C). For the c9 line, grain dry weight of the TR plants showed no significant difference in all three experiments (Fig. 3E).

On the other hand, plants with shorter stature are desirable for high-density planting in the field to increase yield per acre. This laid the foundation for our field test of the $\mathrm{BC}_{2}$ plants using two planting densities. For each of the TR and $\mathrm{NT} \mathrm{BC}_{2}$ plants, the two planting densities did not result in any significant effect on flowering time, plant height, leaf number, average of grain dry weight per plant, or grain quality (Figs. 2, 3). For all of the $\mathrm{BC}_{2}$ plants cross two planting densities, the average of grain dry weight per plant for TR plants $(67.9 \pm 45.5 \mathrm{~g})$ was almost the same as that for NT plants $(67.8 \pm 53.4 \mathrm{~g})$ (Fig. 3F). Notably, while the randomly mixed TR and NT plants grown in each plot were helpful to minimize the errors in this study, the NT plants had advantages over the TR plants in competing for light during the growing season because they were taller after flowering. The unreduced grain weight in the TR plants in the mixed NT/TR field was encouraging. This suggests that a higher yield potential could be achieved for the TR plants when a uniform population were tested in the field. 

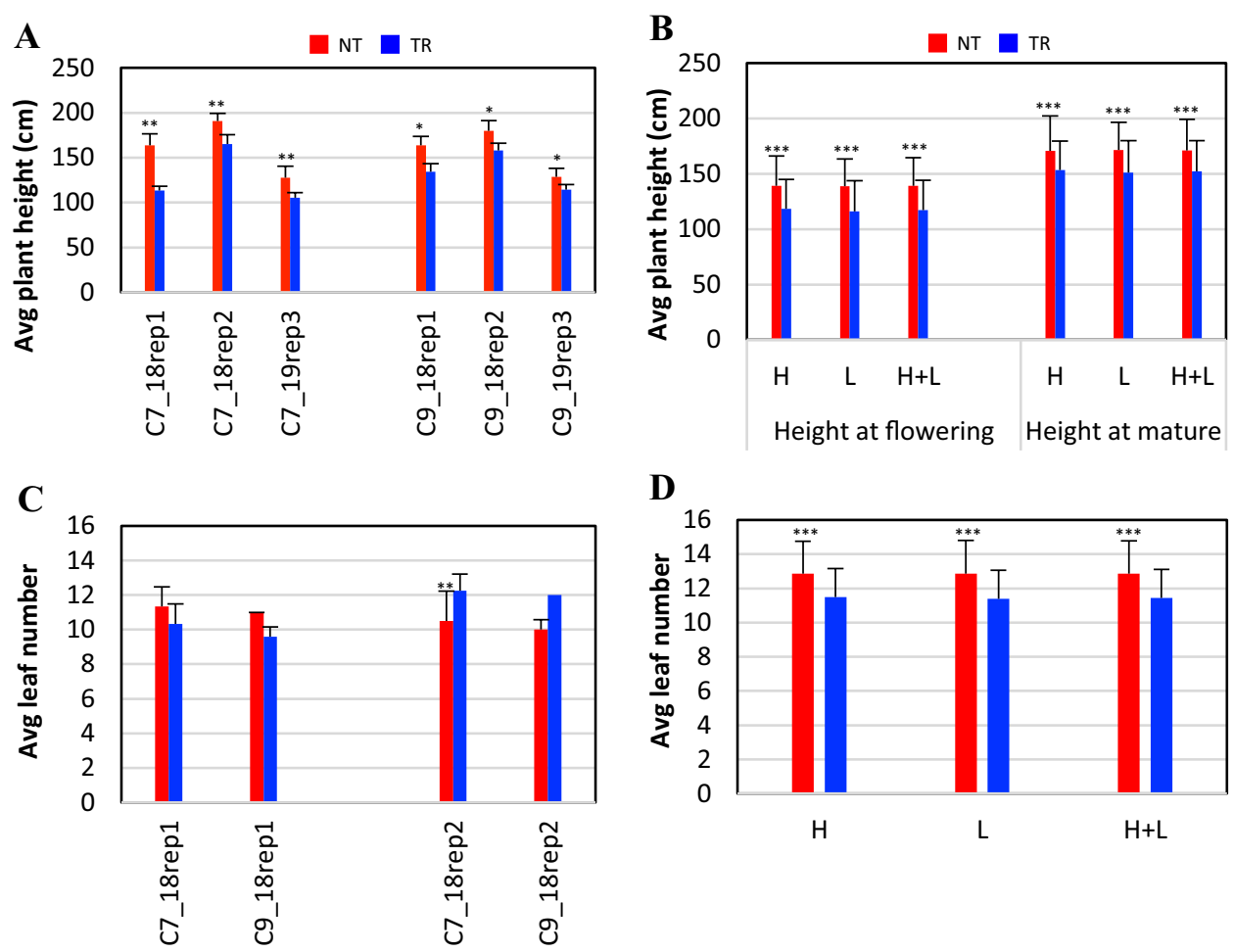

D
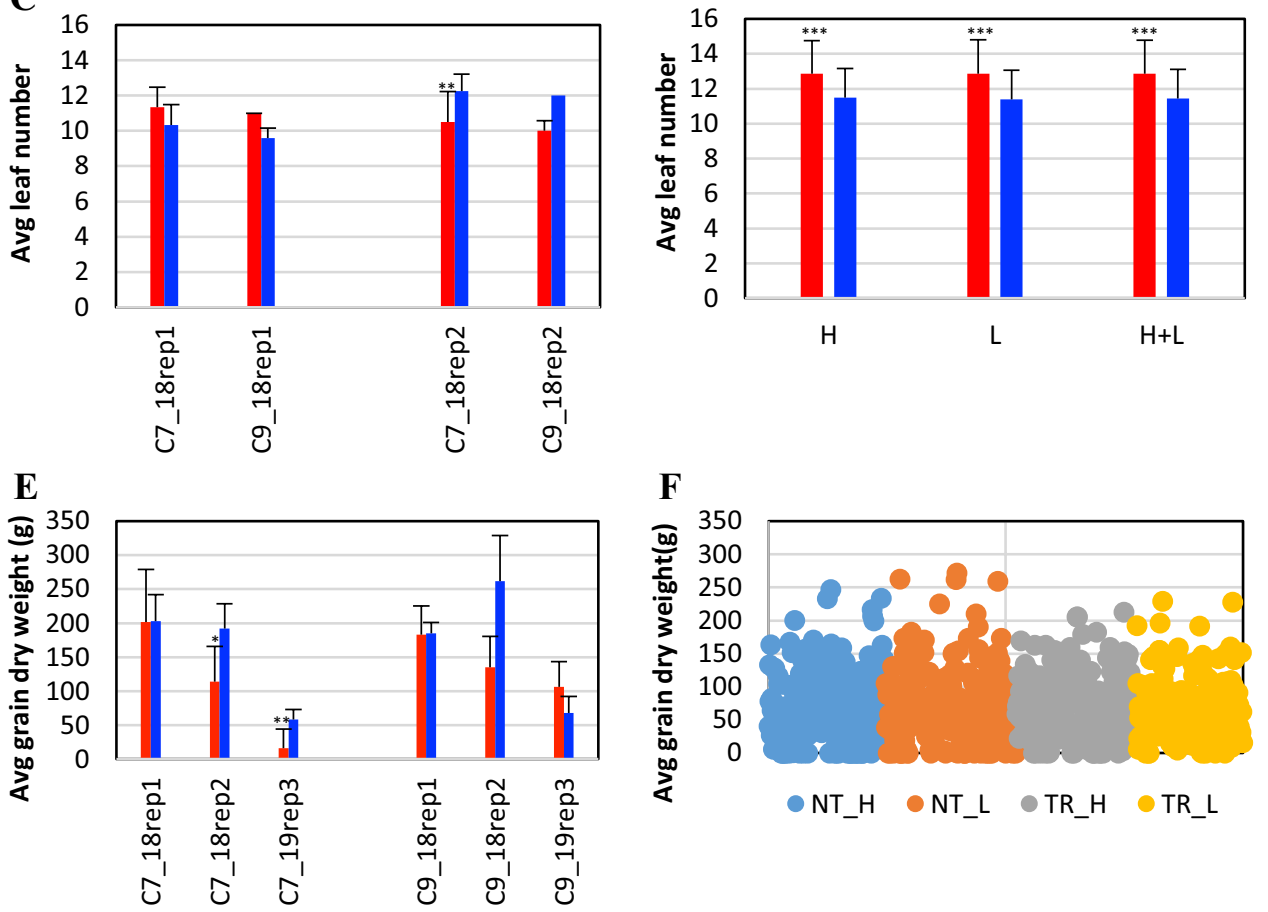

Fig. 3 Plant height and leaf number of transgenic ZmSOC1-OX (TR) and, nontransgenic, null segregant (NT) maize plants of $\mathrm{BC}_{1}$ and $\mathrm{BC}_{2}$ lines. The $\mathrm{BC}_{1}$ plants were from two independent $\mathrm{BC}_{1}$ lines (c7 and c9). Rep1, rep2, and rep3 represent experiment \#1, \#2 and $\# 3$. $\mathrm{BC}_{2}$ seeds from three $\mathrm{c} 7$ lines and three $\mathrm{c} 9$ lines were grown in field. For each $\mathrm{BC}_{2}$ line, 30 plants were randomly grown in each of the six plots, including three plots for a high planting density of 40,000 plants/acre $(H)$ and another three for a low planting density of 32,000 plants/acre $(L)$. A Average plant height of mature $\mathrm{BC}_{1}$ plants. B Average leaf number of mature $\mathrm{BC}_{1}$ plants. $\mathbf{C}$ Average plant height of mature $\mathrm{BC}_{2}$ plants. $\mathbf{D}$ Average leaf number of mature $\mathrm{BC}_{2}$ plants.

\section{Overexpression of $\mathrm{ZmSOC1}$ affects grain quality}

Whether or not an overexpressed MADS-box gene is able to change grain quality is not known. We tested the grain quality from $35 \mathrm{BC}_{2}(12 \mathrm{NT}$ and $23 \mathrm{TR})$ and 15 wild type $\mathrm{B} 73$ plants. TR grain showed a significant increase in starch $(73.1$ vs. $67.7 \%$ in the NT, $p<0.001)$, fat $(4.5$ vs. $3.9 \%, p<0.01)$ and simple sugars content relative to NT grain $(2.4$ vs. $1.8 \%, p<0.05)$ (Table S6). No

E Average grain dry weight per $\mathrm{BC}_{1}$ plant; average grain dry weight per $\mathrm{BC}_{2}$ plant. Star(s) on each bar represent the comparison result between the TR and the NT plants of the same $\mathrm{BC}_{1}$ line in the same experiment, $\mathrm{n}$ for $\mathrm{c} 7$ 18rep1 $\mathrm{NT}=3$, $\mathrm{n}$ for $\mathrm{c} 7 \_$18rep1 $\mathrm{TR}=3$, $\mathrm{n}$ for c7_18rep2 NT=4, n for c7_18rep2 TR=4, n for c7_17rep3 NT=8, $\mathrm{n}$ for c7_19rep3 TR=6, $\mathrm{n}$ for c9_18rep1 $\mathrm{NT}=2$, $\mathrm{n}$ for c9_18rep1 $\mathrm{TR}=5$, n for c9_18rep2 $\mathrm{NT}=5$, $\mathrm{n}$ for c9_18rep2 $\mathrm{TR}=3$, $\mathrm{n}$ for c9_19rep3 NT =3, n for c9_19rep3 TR =8. For the $\mathrm{BC}_{2}$ plants, star(s) on each bar represent the comparison result between the TR and the NT plants of the same planting density. Bars indicate standard deviation. Significance codes: $* * *<0.001, * *<0.01, *<0.05$

significant changes were observed in protein, lignin, or other components.

\section{Overexpression of $\mathrm{ZmSOC1}$ functions at the transcript level}

To reveal the potential impact of ZmSOCl-OX on transgenic plants at transcript levels, we analyzed the transcriptomes in leaves from three TR plants for each of the $\mathrm{c} 7$ and $\mathrm{c} 9$ 
line and three NT plants for the $\mathrm{c} 7$ line, in which the $\mathrm{c} 7 \mathrm{NT}$ plants were genetically similar to c9 NT plants. Transcriptome analysis of $\mathrm{BC}_{1} \mathrm{TR}$ and NT plants was conducted on two major purposes, including to verify the expression of the transgenes and to reveal the genes that responded to the expression of $\mathrm{ZmSOCl}$. Three comparisons were made to reveal DETs induced by ZmSOCl-OX. The comparison of c7 TR and NT resulted in 473 DETs, of which 322 were annotated to 249 unique genes; c9 TR and NT comparison resulted in 2576 DETs, of which 1692 were annotated to 1136 unique genes; and c9 TR and TR comparison resulted in 1,127 DETs, of which 676 were annotated to 485 unique genes (Table S4). The difference of the total number of DETs in the comparisons of the c9 TR and c7 TR likely reflects the genetic background variations and potential transgene insertion elicited changes in the two lines. The shared DETs in the two comparisons, including c9_TR versus NT and c7_TR versus NT, could be the transcripts responding to the overexpression of $\mathrm{ZmSOCl}$.

The Venn diagram in Fig. 4A illustrates the overlap of the DETs from the three transcriptome comparisons. There are 130, 277 and 1,221 DETs that are unique for c7_TR versus NT, c7_TR versus c9_TR and c9_TR versus NT, respectively. Fifty-eight DETs were found from both c7 TR versus NT and c7_TR versus c9_TR, 337 DETs were shared for both c7_TR versus c9_TR and c9_TR versus NT, and 130 DETs were shared for both c9_TR versus NT and c7_TR versus NT. Four DETs appeared to be present in all three transcriptome comparisons (Fig. 4A). These four DETs are NSE4A_ARATH (non-structural maintenance of chromosomes element 4), CP26B_ARATH (peptidyl-prolyl cis-trans isomerase), CHS2_MAIZE (chalcone synthase C2), and RA213_ARATH (ethylene-responsive transcription factor).

Of the annotated DETs, 134 DETs from 107 genes were shared in the two comparisons of c7_TR versus NT and c9_TR versus NT. Among them, 133 out of the 134 DETs were consistent in either up-regulation or down-regulation in the two comparisons (Table S5), including 96,861-fold and 127,973-fold increases of the overexpressed ZmSOC1 (MAD50_ORYSJ) in c7 and c9 TR, respectively (Table 2). The high abundance of ZmSOCl transcript accumulation verified strong expression of $\mathrm{ZmSOC1}$ under the 35S promoter in both the c7 and c9 lines. The 134 shared DETs in the Venn diagram revealed the major genes affected by ZmSOC1-OX at the level of transcription (Table S5). From the 134 DETs, we picked primers to test seven selected DETs using RT-qPCR; the consistency of the RT-qPCR and RNA-seq results suggested that the RNA-seq data were reliable in this study (Fig. 4B, C).

Based on the phenotypic changes observed in $\mathrm{BC}_{1} \mathrm{TR}$ (such as earlier flowering and reduced plant stature, Table 1), we further analyzed the expression of flowering pathway
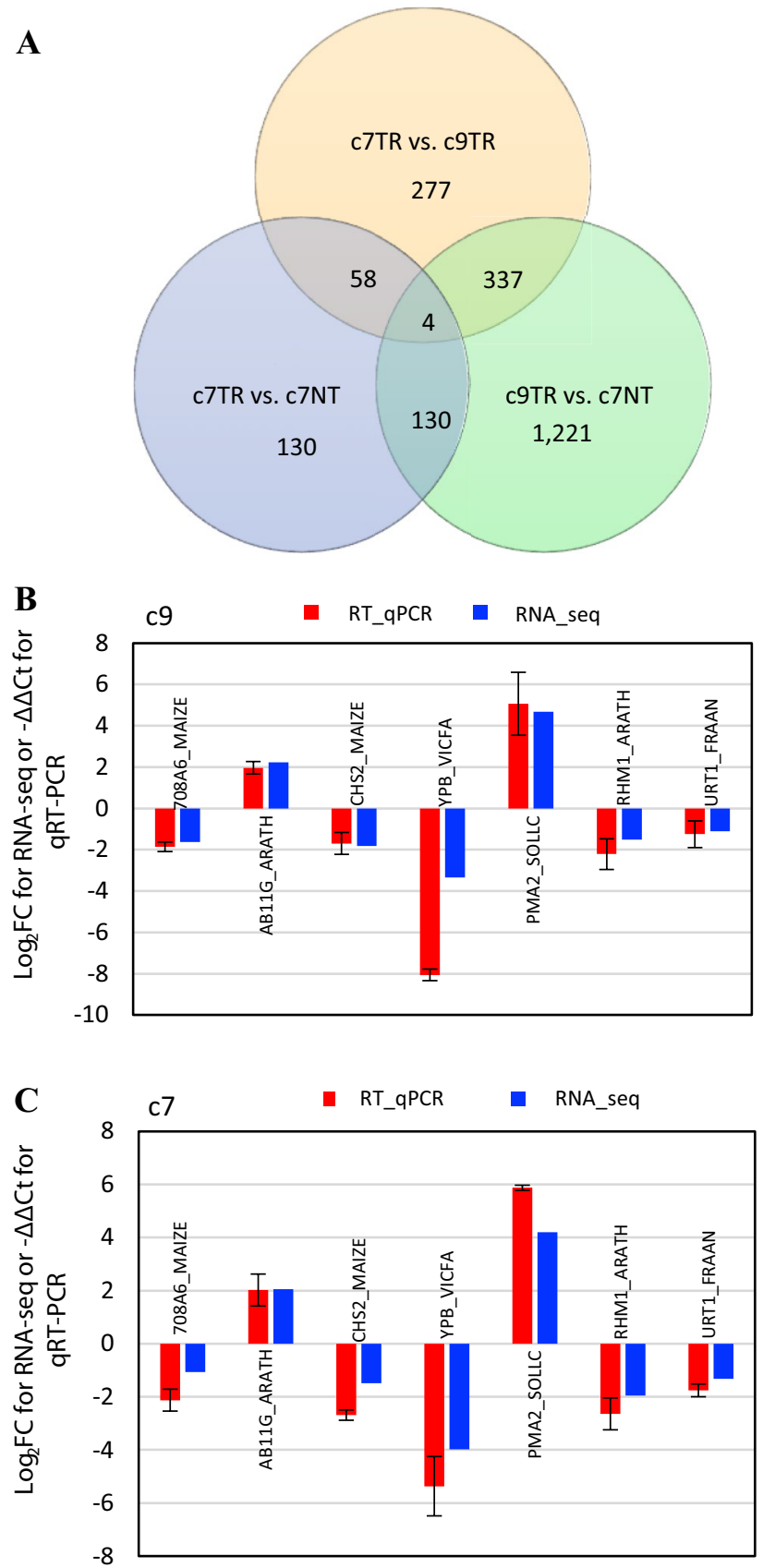

Fig. 4 A Venn diagram illustrating overlap of the three transcriptomic comparisons of the annotated, differentially expressed transcripts (DETs) among $\mathrm{BC}_{1}$ null segregant $\mathrm{c} 7 \mathrm{NT}$ and two transgenic ZmSOC1_OX lines of c7TR and c9TR. B, C Comparison of the RTqPCR analysis result and the RNA-seq data of the selected DETs (Table 2, Table S5). $-\Delta \Delta \mathrm{Ct}$ is an average of three biological and three technical replicates for each DET. ZmActin1 (SAC1_ARATH) was used to normalize the RT-qPCR results. Bars indicate standard deviation

genes and hormone-related genes. Twenty-one DETs of 14 genes were shared in the two comparisons of c7_TR versus NT and c9_TR versus NT (Table 2). In the flowering pathways, expression of two endogenous $\mathrm{ZmSOCl}$ genes 
Table 2 Differentially expressed transcripts (DETs) of flowering pathway and hormone genes in maize leaves during the fast-growing stage of the plants before flowering $\left[\log _{2} \mathrm{FC}: \log _{2}(\right.$ Fold change $)=\log _{2}(\mathrm{TR} / \mathrm{NT})$

\begin{tabular}{|c|c|c|c|c|c|c|c|c|c|}
\hline $\begin{array}{l}\text { Maize__ } \\
\text { transcript } \\
\text { _id }\end{array}$ & Annotation & $\begin{array}{l}\text { Annotation_e_ } \\
\text { value }\end{array}$ & $\begin{array}{l}\text { C7 DE_ } \\
\log \mathrm{FC}\end{array}$ & $\begin{array}{l}\text { C9 DE_ } \\
\operatorname{logFC}\end{array}$ & $\%$ identity & $\begin{array}{l}\text { Blast-e } \\
\text { value }\end{array}$ & Gene_ID & Gene_name & Pathway \\
\hline $\begin{array}{l}\text { DN20371_- } \\
\text { c2_g4_i2 }\end{array}$ & $\begin{array}{l}\text { DOF54_ } \\
\text { ARATH }\end{array}$ & $8.89 \mathrm{E}-30$ & 7.16 & 6.71 & 74.1 & $1.42 \mathrm{E}-24$ & AT2G34140.1 & $\begin{array}{l}\text { CYCLING } \\
\text { DOF FAC- } \\
\text { TOR } 4 \\
(\mathrm{CDF} 4)\end{array}$ & Flowering \\
\hline $\begin{array}{l}\text { DN22669_- } \\
\text { c0_g2_i4 }\end{array}$ & $\begin{array}{l}\text { GIGAN_ }_{-} \\
\text {ORYSJ }\end{array}$ & 0 & 9.05 & 8.86 & 63.9 & $0.00 \mathrm{E}+00$ & AT1G22770.1 & $\begin{array}{l}\text { GIGANTEA } \\
\text { (GI) (ZmGI) }\end{array}$ & Flowering \\
\hline $\begin{array}{l}\text { DN18903_- } \\
\text { c0_g1_i3 }\end{array}$ & $\begin{array}{l}\text { TRPA_ } \\
\text { MAIZE }\end{array}$ & $2.69 \mathrm{E}-133$ & -3.06 & -4.52 & 60.8 & $1.33 \mathrm{E}-113$ & AT4G02610.1 & & Auxin \\
\hline $\begin{array}{l}\text { DN19326_- } \\
\text { c1_g1_i1 }\end{array}$ & $\begin{array}{l}\text { C78A6_ } \\
\text { ARATH }\end{array}$ & $1.43 \mathrm{E}-164$ & 1.81 & 1.36 & 27.9 & $9.20 \mathrm{E}-48$ & AT4G31500.1 & $\begin{array}{l}\text { RNT1, RED1, } \\
\text { SUR2, } \\
\text { ATR4, } \\
\text { CYP83B1 }\end{array}$ & Auxin \\
\hline $\begin{array}{l}\text { DN19326_- } \\
\text { c1_g1_i2 }\end{array}$ & $\begin{array}{l}\text { C78A6_ } \\
\text { ARATH }\end{array}$ & $9.29 \mathrm{E}-174$ & 1.94 & 1.43 & 30.9 & $4.45 \mathrm{E}-55$ & AT4G31500.1 & $\begin{array}{l}\text { RNT1, RED1, } \\
\text { SUR2, } \\
\text { ATR4, } \\
\text { CYP83B1 }\end{array}$ & Auxin \\
\hline $\begin{array}{l}\text { DN18903_- } \\
\text { c0_g1_i1 }\end{array}$ & $\begin{array}{l}\text { TRPA_- } \\
\text { MAIZE }\end{array}$ & $2.38 \mathrm{E}-103$ & -3.38 & -5.05 & 51.1 & $2.41 \mathrm{E}-88$ & AT4G02610.1 & & Auxin \\
\hline $\begin{array}{l}\text { DN12409_- } \\
\text { c0_g2_i1 }\end{array}$ & $\begin{array}{l}\text { 708A6_ } \\
\text { MAIZE }\end{array}$ & $2.63 \mathrm{E}-144$ & -2.13 & -1.86 & 29.5 & 2.69E-39 & AT2G36800.1 & $\begin{array}{l}\text { UGT73C5, } \\
\text { DOGT1 }\end{array}$ & $\begin{array}{l}\text { Brassinos- } \\
\text { teroid }\end{array}$ \\
\hline $\begin{array}{l}\text { DN9072_- } \\
\text { c0_g1_i3 }\end{array}$ & $\begin{array}{l}\text { URT1 } \\
\text { FRAAN }\end{array}$ & $5.49 \mathrm{E}-72$ & -1.75 & -1.25 & 28.2 & $3.70 \mathrm{E}-32$ & AT2G36800.1 & $\begin{array}{l}\text { UGT73C5, } \\
\text { DOGT1 }\end{array}$ & $\begin{array}{l}\text { Brassinos- } \\
\text { teroid }\end{array}$ \\
\hline $\begin{array}{l}\text { DN20315_- } \\
\text { c0_g6_i1 }\end{array}$ & $\begin{array}{c}\text { ACCO1_ } \\
\text { ORYSJ }\end{array}$ & $2.70 \mathrm{E}-97$ & 1.68 & 2.09 & 71.4 & 8.09E-78 & AT1G62380.1 & $\begin{array}{c}\text { ATGA2OX8, } \\
\text { GA2OX8 }\end{array}$ & Ethylene \\
\hline $\begin{array}{l}\text { DN15903_- } \\
\text { c0_g1_- } \\
\text { i16 }\end{array}$ & $\begin{array}{r}\text { ACCO1_- } \\
\text { ORYSJ }\end{array}$ & $1.03 \mathrm{E}-161$ & 2.93 & 2.71 & 60.3 & $3.19 \mathrm{E}-125$ & AT1G62380.1 & $\begin{array}{l}\text { ATACO } 2, \\
\text { ACO2 }\end{array}$ & Ethylene \\
\hline $\begin{array}{l}\text { DN22035_- } \\
\text { c0_g2_i1 }\end{array}$ & $\begin{array}{l}\text { AAMT3 } \\
\text { MAIZE }\end{array}$ & 0 & -2.98 & -3.93 & 25.7 & $1.54 \mathrm{E}-35$ & AT5G56300.1 & GAMT2 & Gibberellin \\
\hline $\begin{array}{l}\text { DN22319_ } \\
\text { c0_g1_- } \\
\text { i20 }\end{array}$ & \#N/A & \#N/A & 8.12 & 8.28 & 68.6 & $8.75 \mathrm{E}-44$ & AT3G24715.1 & HCR1 & \\
\hline $\begin{array}{l}\text { DN15759_- } \\
\text { c1_g2_i4 }\end{array}$ & $\begin{array}{l}\text { P2C27_- } \\
\text { ORYSJ }\end{array}$ & $1.26 \mathrm{E}-151$ & 8.45 & 9.01 & 36.1 & $2.60 \mathrm{E}-35$ & AT2G30020.1 & $\mathrm{AP} 2 \mathrm{C} 1$ & \\
\hline $\begin{array}{l}\text { DN16626_- } \\
\text { c0_g3_i2 }\end{array}$ & $\begin{array}{l}\text { MAD50 } \\
\text { ORYSJ }\end{array}$ & $5.23 \mathrm{E}-116$ & -2.03 & -1.41 & 62 & $3.97 \mathrm{E}-88$ & $\begin{array}{l}\text { LOC }_{-} \\
\quad \text { Os10g39130.1 }\end{array}$ & $\begin{array}{r}\text { OsMADS56 } \\
(\mathrm{ZmSOC} 1)\end{array}$ & Flowering \\
\hline $\begin{array}{l}\text { DN16626_- } \\
\text { c0_g2_i8 }\end{array}$ & $\begin{array}{l}\text { MAD56_- } \\
\text { ORYSI }\end{array}$ & $8.66 \mathrm{E}-105$ & -1.42 & -1.36 & 69.4 & $8.03 \mathrm{E}-105$ & $\begin{array}{l}\text { LOC }_{-} \\
\quad \text { Os10g39130.1 }\end{array}$ & $\begin{array}{r}\text { OsMADS56 } \\
(\mathrm{ZmSOC} 1)\end{array}$ & Flowering \\
\hline $\begin{array}{l}\text { DN21779_- } \\
\text { c0_g3_i1 }\end{array}$ & $\begin{array}{l}\mathrm{HD}_{\mathrm{A}}{ }_{-} \\
\text {ORYSJ }\end{array}$ & $2.60 \mathrm{E}-99$ & 4.06 & 3.83 & 95.5 & $1.48 \mathrm{E}-103$ & $\begin{array}{l}\text { LOC }_{-} \\
\quad \text { Os01g11940.1 }\end{array}$ & $\begin{array}{l}\text { osFTL1 } \\
\text { FT-Like1 } \\
\text { (ZmFT) }\end{array}$ & Flowering \\
\hline $\begin{array}{l}\text { DN15967_- } \\
\text { c0_g7_i1 }\end{array}$ & $\begin{array}{l}\text { MAD15 } \\
\text { ORYSJ }\end{array}$ & $6.76 \mathrm{E}-32$ & 4.54 & 4.68 & 98.2 & $1.71 \mathrm{E}-30$ & $\begin{array}{l}\text { LOC_ }_{-} \\
\quad \text { Os07g01820.1 }\end{array}$ & $\begin{array}{c}\text { OsMADS15 } \\
\text { (ZmAP1) }\end{array}$ & Flowering \\
\hline $\begin{array}{l}\text { DN17448_- } \\
\text { c1_g1_i3 }\end{array}$ & $\begin{array}{r}\text { MAD15_- } \\
\text { ORYSJ }\end{array}$ & $9.03 \mathrm{E}-120$ & 5.92 & 5.58 & 73.2 & $9.67 \mathrm{E}-112$ & $\begin{array}{l}\mathrm{LOC}_{-} \\
\quad \text { Os07g01820.1 }\end{array}$ & $\begin{array}{c}\text { OsMADS15 } \\
\text { (ZmAP1) }\end{array}$ & Flowering \\
\hline $\begin{array}{l}\text { DN17448_- } \\
\text { c1_g1_i6 }\end{array}$ & $\begin{array}{l}\text { MAD15 } \\
\text { ORYSJ }\end{array}$ & $1.28 \mathrm{E}-114$ & 6.98 & 5.84 & 73 & $7.65 \mathrm{E}-108$ & $\begin{array}{l}\text { LOC_ }_{-} \\
\text {Os07g01820.1 }\end{array}$ & $\begin{array}{c}\text { OsMADS15 } \\
\text { (ZmAP1) }\end{array}$ & Flowering \\
\hline $\begin{array}{l}\text { DN16626_- } \\
\text { c0_g3_i } 8^{\mathrm{a}}\end{array}$ & $\begin{array}{l}\text { MAD50 } \\
\text { ORYSJ }\end{array}$ & $1.12 \mathrm{E}-116$ & 16.55 & 16.97 & 62 & $1.11 \mathrm{E}-88$ & $\begin{array}{l}\text { LOC }_{-} \\
\text {Os10g39130.1 }\end{array}$ & $\begin{array}{r}\text { OsMADS56 } \\
\text { (ZmSOC1) }\end{array}$ & Flowering \\
\hline $\begin{array}{l}\text { DN20803_- } \\
\text { c2_g1_i7 }\end{array}$ & $\begin{array}{l}\text { HSP7R_ } \\
\text { ARATH }\end{array}$ & 0 & -1.91 & -1.56 & 30.4 & $2.03 \mathrm{E}-53$ & AT1G56410.1 & $\begin{array}{l}\text { HSP70T-1, } \\
\text { ERD2 }\end{array}$ & Sucrose \\
\hline
\end{tabular}

The bold DETs were verified by RT-qPCR. None of the DETs included in the table were the DETs in the comparison of the c7 TR and c9 TR $N / A$ not annotated to known gene(s) or no $e$ value

${ }^{\mathrm{a}}$ Overexpressed ZmSOC1 
was downregulated, and expression of four genes annotated as MAD15_ORYSJ, HD3A_ORYSJ, GIGAN_ORYSJ, and DOF54_ARATH was upregulated. MAD15_ORYSJ is an ortholog of Arabidopsis AP1, and HD3A_ORYSJ is an ortholog of Arabidopsis FLOWERING LOCUS T (FT). Both of them are positive regulators in plant flowering that interact directly with SOC1 (Fornara et al. 2010). GIGANTEA $(G I)$ is an upstream regulator of CONSTANS $(C O)$ and $F T$ in the circadian clock-controlled flowering pathway of Arabidopsis, and promotes the expression of the downstream flowering-time genes (Mizoguchi et al. 2005). GIGAN_ORYSJ, an ortholog of GI, showed increased expression of 530- and 465-fold for the c7 TR and c9 TR, respectively (Table 2). Overall, the highly upregulated GIGAN_ORYSJ, MAD15_ ORYSJ (23-126 fold), and HD3A_ORYSJ (14-16 fold) and markedly reduced flowering time in both the c7 TR and c9 TR are likely the results of the overexpressed ZmSOC1 in these plants (Fig. 5A).

The detected DETs in the pathways of auxin, brassinosteroid, ethylene, and gibberellin contributed to many observed phenotypes (e.g., reduced plant stature and the increased growth of the c7 and c9 TR plants during their vegetative growth) and nonvisible biochemical and physiological changes. DNA binding with one finger 5.4 (DOF5.4) is a transcription factor that negatively regulates cell cycle and cell expansion; enhanced expression of DOF5.4/OBP4 leads to plant dwarfing in Arabidopsis (Xu et al. 2016). In the $\mathrm{c} 7$ and c9 TR plants, DOF54_ARATH expression was upregulated to 143- and 104-fold, respectively (Table 2), supporting that the increase in expression of DOF54_ARATH may play a significant role in the reduced plant height of the $\mathrm{c} 7$ and c9 TR plants (Fig. 5A). Brassinosteroids (BRs) can promote plant growth and BR-deficient mutant plants often exhibit dwarfing (Fujioka and Yokota 2003; Grove et al. 1979; Kim et al. 2000; Mussiget al. 2003; Tanabe et al. 2005). In the BR pathway of Arabidopsis, UDP-GLYCOSYLTRANSFERASE 73C5 (UGT73C5) catalyzes inactivation of BRs and can lead to dwarfed BR-deficient plants (Poppenberger et al. 2005), which is often undesirable for crop yield. The DETs of both 708A6_MAIZE and URT1_FRAAN had high similarities $(\mathrm{e}<-20)$ to $U G T 73 C 5$, and both transcripts showed decreased expression of $23-42 \%$ and had the potential for an increase in BRs that often benefits plant development (Table 2). It is possible that the decreased expression of 708A6_MAIZE and URT1_FRAAN was responsible for the increased growth of $\mathrm{c} 7$ and $\mathrm{c} 9$ TR plants during their vegetative growth. Of the auxin-related DETs, expression of TRPA_MAIZE with its function unknown was downregulated to 3-12\%; expression of C78A6_ARATH was upregulated to 2.6-3.8 fold in the c7 and c9 TR plants (Table 2).
Fig. 5 Major differentially expressed transcripts (DETs) and their potential functions (A) and gene networks of the shared DETs in leaf tissues of transgenic ZmSOC1_OX plants (B). The ontology file of GOSlim_Plants in BiNGO was used to identify overrepresented GO terms $(p<0.05)$. Bubble size and color indicate the frequency of the GO term and the $p$ value, respectively

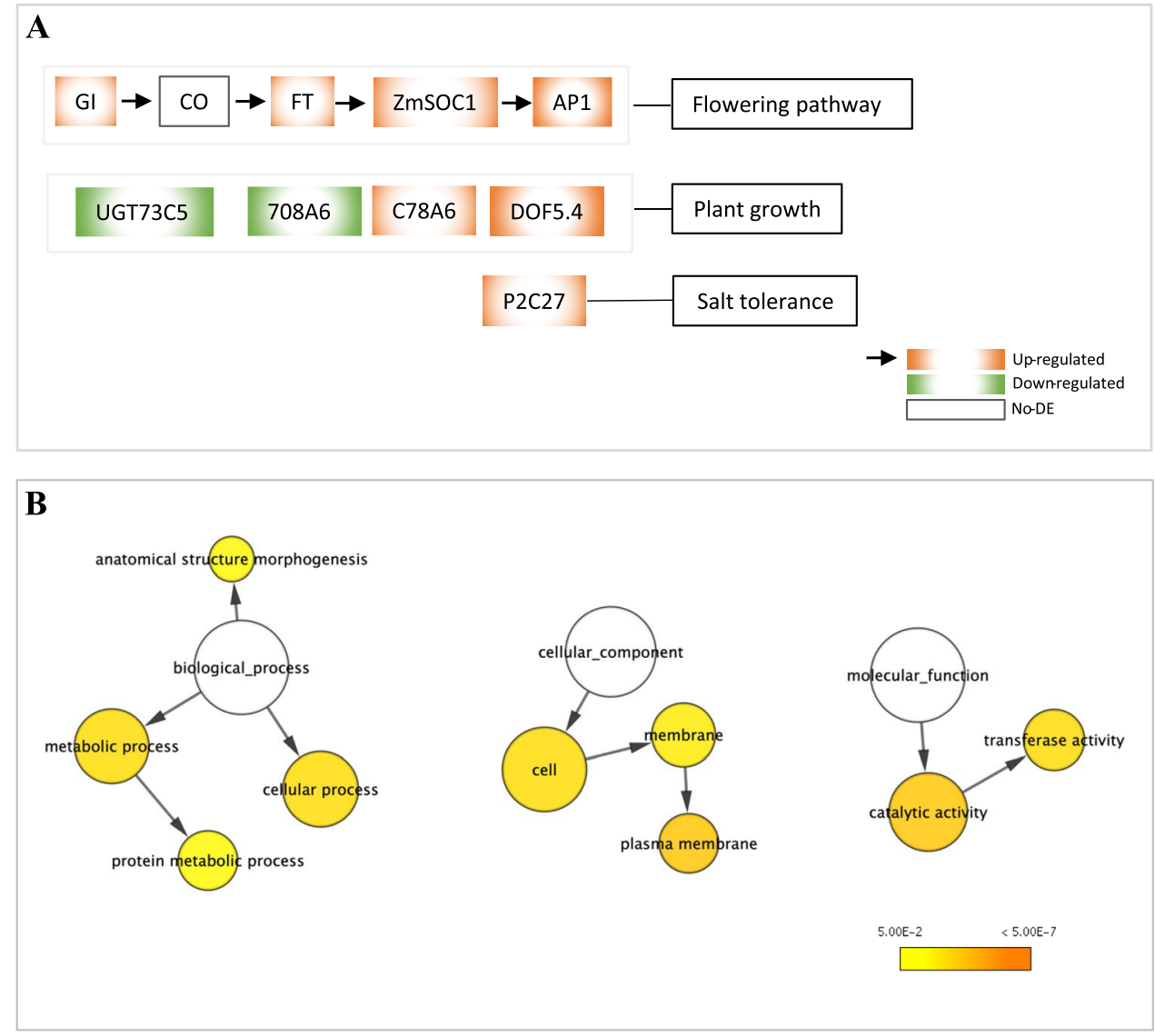


Notably, the increased expression of C78A6_ARATH may result in increased size of leaves, flowers and seeds, but defects in reproductive development (Fang et al. 2012). Both the $\mathrm{c} 7$ and c9 TR plants did not exhibit defects in reproductive development, but leaf and seed sizes were not investigated in this study. PROBABLE PROTEIN POSPHATASE 2C 27 (P2C27_ORYSJ) triggers the expression of stressresponsive genes in Arabidopsis (Liu et al. 2012); the increased expression of maize $P 2 C 27$ could enhance salt tolerance in transgenic plants. Two ethylene-related, one gibberellin-related, and one sucrose-related DETs were also detected, although none of them seemed to have a close correlation with the phenotypic changes observed (Table 2). Overall, these major DETs driven by ZmSOC1-OX were the most likely candidates responsible for the phenotypic changes.

In addition to the DETs of flowering pathway and hormone-related genes, the other DETs also likely played a role in the overall phenotypic changes of the TR plants (Table 2, Fig. 5A, Table S5). To reveal the overall impact of the DETs detected in the c7 TR plants, GOSlim_Plants in Cytoscape 3.8.2 was used to visualize the overrepresented Gene Ontology (GO) terms. As shown in Fig. 5, a total of nine GO terms were overrepresented or enriched $(p<0.05)$. Four overrepresented terms in the biological process are "metabolic process", "cellular process", "protein metabolic process", and "anatomical structure morphogenesis", supporting that multiple biological processes were affected by the ZmSOCl-OX. Three overrepresented terms in the cellular component include "cell", membrane", and "plasma membrane", suggesting that the phenotypic changes may be related to these cellular components. In the molecular function, two overrepresented GO terms are "transferase activity" and "catalytic activity" (Fig. 5B). More details of the overrepresented GO terms and their networks can be visualized using GO_full (Fig. S4). At a gene network level, the overrepresented GO terms reveal the overall impact of ZmSOCl overexpression on plant growth, flowering, yield potential, or grain quality.

\section{Discussion}

Genetically modified (GM) crops for yield boosting are desirable to increase productivity without increasing land use, although they are not yet available on the market (ISAAA's GM Approval Database. http://www.isaaa.org/ gmapprovaldatabase/). In our efforts to produce GM crops for boosting yield, we chose the SOC1 MADS-box gene as a target due to its significant role as a major integrator in the plant flowering pathway (Fornara et al. 2010; Lee and Lee 2010; Song and Chen 2018; Song et al. 2013). In this study, we cloned the $\mathrm{ZmSOCl}$ gene to explore the potential of utilizing this gene to increase maize grain production. The $\mathrm{ZmSOCl}$ was transformed into maize $\mathrm{Hi}-\mathrm{II}$. $\mathrm{BC}_{1}$ plants of nine transgenic lines were grown in three experiments to evaluate phenotypic changes of nine traits between transgenic and nontransgenic plants in each $\mathrm{BC}_{1}$ line population. We also conducted transcriptome analysis of six transgenic and three nontransgenic plants to reveal the DETs driven by ZmSOCl overexpression. We demonstrated that manipulation of the expression of $\mathrm{ZmSOCl}$ is a powerful approach to increase maize yield.

SOCl is a key pathway integrator and flower activator (Lee et al. 2000; Lee and Lee 2010; Moonet al. 2003). In monocots, functional SOCl orthologues have been identified and demonstrated to be flowering activators (Alter et al. 2016; Lee et al. 2004; Ryuet al. 2009). Functional analysis of maize ZmMADS1 through both overexpression and RNA interference-mediated down-regulation has confirmed that maize $Z m M A D S 1$ is a functional $S O C 1$ orthologue of maize (ZmSOC1) (Alter et al. 2016). In the overexpression experiment, transgenic plants (offspring of two lines) overexpressing the $\mathrm{ZmSOCl}$ using the maize ubiquitin promoter showed early flowering, decreased leaf number, and reduced plant height compared to nontransgenic maize plants under greenhouse conditions (Alter et al. 2016). Our data, based on the field evaluation of the $\mathrm{BC}_{2}$ plants from six lines, also found overexpression of $\mathrm{ZmSOCl}$ driven by $35 \mathrm{~S}$ promoter was able to promote flowering and reduce plant height and leaf number. In addition, our work demonstrated that $\mathrm{ZmSOCl-OX}$ approach can be adopted to enhance maize yield potential.

Orthologues of SOCl in many plant species have been studied to reveal flowering mechanisms (Lee and Lee 2010). However, efforts using SOCl orthologues to increase crop yield have not been documented. Regardless of the results from potted plants in this study, the increased grain production per TR plant suggests that ZmSOCl-OX, at least in some transgenic lines, has potential to increase maize grain yield. Additionally, the reduced plant height suggests that TR plants can be planted at a higher density, potentially increasing maize grain yield per acre. More experiments are ongoing to investigate $\mathrm{BC}_{2}$ plants growing with different planting densities under field conditions.

MADS-box transcription factors (TFs) function at almost every aspect of plant reproductive development through a complex protein-protein interaction network (Hugouvieux and Zubieta 2018). In Arabidopsis, CONSTANS (CO) activates $S O C 1$ through $F T$ to promote flowering (Yoo et al. 2005). In this study, comparative transcriptome analysis revealed that ZmSOCl-OX enhanced expression of maize FLOWERING LOCUS T (ZmFT) and maize GIGANTEA $(Z m G I)$ genes. The result is similar to that observed in transgenic rice where rice $S O C 1$ was overexpressed (Lee et al. 2004). In maize, the orthologue of FUL (ZMM28) is the MADS-box gene considered to be a duplication of the 
maize $A P 1$ gene; it has been successfully used for increasing grain yield through overexpression (Wu et al. 2019). In this study, the overexpressed ZmSOCl enhanced expression of the downstream API MADS-box gene annotated as ZmAP1, but not the FUL gene (ZMM28), suggesting that ZMM28 is not a direct target at transcript level by overexpressed $\mathrm{ZmSOC1}$ at the developmental stage tested. On the other hand, both ZmSOC1-OX and ZMM28 could be essential at protein levels (Abraham-Juarez et al. 2020). In Arabidopsis, the functions of $A P I$ and $F U L$ are partially overlapping. The sequence difference in ZmAP1 and ZMM28 may be responsible for their divergence in responding to the overexpressed ZmSOC1 (Kater et al. 2006; McCarthy et al. 2015).

The increased grain yield in the selected maize ZMM28overexpression line DP202216 was attributed to increased early plant vigor and total leaf area (Wu et al. 2019). Similarly, the overexpressed $\mathrm{ZmSOCl}$ also increased plant vigor in this study. Phenotypic variations in the nine $\mathrm{BC}_{1}$ transgenic lines tested have suggested that there is high potential to identify ideal transgenic lines for high grain yield. Backcrosses of the selected ZmSOC1-OX line to B73 are ongoing to produce new inbred $\mathrm{B} 73$ lines containing homozygous ZmSOC1-OX for field trials and commercialization of the ZmSOC1-OX technology. In addition, further studies are still needed to determine transgene insertion position(s), copy number, and the correlation between the $\mathrm{ZmSOCl}$ expression levels and the phenotypic changes in all 16 transgenic lines we produced. Taken together, modulating expression of MADS-box genes (e.g., the $\mathrm{ZmSOCl}$ in this report) opens a new approach to enhance crop yield or change grain quality.

\section{Conclusions}

This is the first investigation of using a SOCl gene to increase the potential for high grain yield. Overexpression of $\mathrm{ZmSOCl}$ accelerated flowering, reduced plant stature, and increased/unreduced grain dry weight of the $\mathrm{BC}_{1}$ and $\mathrm{BC}_{2}$ TR plants grown under natural conditions. In addition, the grain of BC2 TR plants showed an increase in the content of starch, simple sugars, and fat. Transcriptome analysis revealed potential genes responding to ZmSOC1-OX. Overall, the results facilitate a better understanding of $\mathrm{SOCl}$ regulated growth and flowering in maize. More importantly, modulating expression of $S O C 1$ opens a new and effectual approach to promote flowering and reduce plant height, which may have the potential to enhance crop yield and improve grain quality.

Author contributions statement GS conceived and supervised the study; GS, XH, and JR conducted the experiments; $\mathrm{KW}$ supervised the production of transgenic maize at Iowa State University Plant Transformation Facility; AT and GS designed the field trials; GS analyzed data; and GS and KW wrote the manuscript. All authors read and approved the final manuscript.

Supplementary Information The online version contains supplementary material available at https://doi.org/10.1007/s00299-021-02722-4.

Acknowledgements We thank Mr. Pete Callow, Mrs. Dongmei Yin, Dr. Xiaoyan Han, Ms. Linsey Newton, Mr. Bill Chase, and Mr. Randy Klevickas for the help with field data collection. We thank Dr. Wayne Loescher and Mr. Aaron Walworth for the review of this manuscript. The work was supported under the MTRAC Program sponsored by the State of Michigan 21st Century Jobs Fund received through the Michigan Strategic Fund and administered by the Michigan Economic Development Corporation, and it was also supported partially by AgBioResearch of Michigan State University (http://www.canr.msu.edu/ research/agbioresearch/).

Funding The work was supported under the MTRAC Program sponsored by the State of Michigan 21st Century Jobs Fund received through the Michigan Strategic Fund and administered by the Michigan Economic Development Corporation, and it was also supported partially by AgBioResearch of Michigan State University (http://www. canr.msu.edu/research/agbioresearch/).

\section{Declarations}

Conflict of interest The authors have no conflicts of interest to declare.

Ethics approval This article does not contain any studies with human participants or animals.

Open Access This article is licensed under a Creative Commons Attribution 4.0 International License, which permits use, sharing, adaptation, distribution and reproduction in any medium or format, as long as you give appropriate credit to the original author(s) and the source, provide a link to the Creative Commons licence, and indicate if changes were made. The images or other third party material in this article are included in the article's Creative Commons licence, unless indicated otherwise in a credit line to the material. If material is not included in the article's Creative Commons licence and your intended use is not permitted by statutory regulation or exceeds the permitted use, you will need to obtain permission directly from the copyright holder. To view a copy of this licence, visit http://creativecommons.org/licenses/by/4.0/.

\section{References}

Abraham-Juarez MJ, Schrager-Lavelle A, Man J, Whipple C, Handakumbura P, Babbitt C, Bartlett M (2020) Evolutionary variation in MADS Box dimerization affects floral development and protein abundance in maize. Plant Cell 32:3408-3424

Adamczyk BJ, Fernandez DE (2009) MIKC* MADS domain heterodimers are required for pollen maturation and tube growth in Arabidopsis. Plant Physiol 149:1713-1723

Alter P, Bircheneder S, Zhou LZ, Schluter U, Gahrtz M, Sonnewald U, Dresselhaus T (2016) Flowering time-regulated genes in maize include the transcription factor ZmMADS1. Plant Physiol 172:389-404 
Amasino R (2010) Seasonal and developmental timing of flowering. Plant J 61:1001-1013

Anderson JA, Brustkern S, Cong B, Deege L, Delaney B, Hong BN, Lawit S, Mathesius C, Schmidt J, Wu JRR, Zhang J, Zimmermann C (2019a) Evaluation of the history of safe use of the maize ZMM28 protein. J Agr Food Chem 67:7466-7474

Anderson JA, Hong B, Moellring E, TeRonde S, Walker C, Wang Y, Maxwell C (2019b) Composition of forage and grain from genetically modified DP202216 maize is equivalent to non-modified conventional maize (Zea mays L.). GM Crops Food 10:13

Ash C, Jasny BR, Malakoff DA, Sugden AM (2010) Food security. Feeding the future introduction. Science 327:797

Bae JM, Noh SA, Kwak MS, Shin JS, Lee HS (2011) Sweetpotato mads-box promoter directing high level expression in plant storage root. In: Google Patents. Available online at https://patents. google.com/patent/US7273967B2/en. Accessed 3 June 2021

Becker A, Theissen G (2003) The major clades of MADS-box genes and their role in the development and evolution of flowering plants. Mol Phylogenet Evol 29:464-489

Cacharron J, Theissen G, Deleu W, Saedler H (2000) Mads-box genes and uses thereof. In: Google Patents. Available online at https:// patents.google.com/patent/WO2018213538A1/en. Accessed 3 June 2021

Castelan-Munoz N, Herrera J, Cajero-Sanchez W, Arrizubieta M, Trejo C, Garcia-Ponce B, Sanchez MP, Alvarez-Buylla ER, Garay-Arroyo A (2019) MADS-Box genes are key components of genetic regulatory networks involved in abiotic stress and plastic developmental responses in plants. Front Plant Sci 10:853

Catron SA (2019) Petition for Determination of Nonregulated Status for Enhanced Grain Yield Potential and Glufosinate-ammonium Resistant DP202216 Maize. Available online at https://www. aphis.usda.gov/brs/aphisdocs/19-10101p-ppra.pdf. Accessed 3 June 2021

Causier B, Kieffer M, Davies B (2002) Plant biology. MADS-Box genes reach maturity. Science 296:275-276

Danilevskaya O, Bruce W (2008) Yield enhancement in plants by modulation of maize mads box transcription factor ZMM28. Available online at https://patents.google.com/patent/WO2008148872A1. Accessed 3 June 2021

Doyle JJ, Doyle JL (1987) A rapid DNA isolation procedure for small quantities of fresh leaf tissue. PHYTOCHEMICAL BULLETIN 19:5

Dreni L, Kater MM (2014) MADS reloaded: evolution of the AGAMOUS subfamily genes. New Phytol 201:717-732

Dreni L, Zhang D (2016) Flower development: the evolutionary history and functions of the AGL6 subfamily MADS-box genes. J Exp Bot 67:1625-1638

Fang W, Wang Z, Cui R, Li J, Li Y (2012) Maternal control of seed size by EOD3/CYP78A6 in Arabidopsis thaliana. Plant J 70:929-939

Fornara F, de Montaigu A, Coupland G (2010) SnapShot: control of flowering in Arabidopsis. Cell 141:550

Frame B, Warnberg K, Main M, Wang K (2015) Maize (Zea mays L.). In: Wang K (ed) Agrobacterium protocols, 3rd edn. Springer, New York, pp 101-117

Fujioka S, Yokota T (2003) Biosynthesis and metabolism of brassinosteroids. Annu Rev Plant Biol 54:137-164

Garcia-Maroto F, Carmona MJ, Garrido JA, Vilches-Ferron M, Rodriguez-Ruiz J, Alonso DL (2003) New roles for MADS-box genes in higher plants. Biol Plantarum 46:321-330

Giovannoni JJ, Friedman H, Vrebalov J, Elitzer T (2013) Banana madsbox genes for banana ripening control. In: Google Patents. Available online at https://patents.google.com/patent/US20130036 515A1/en. Accessed 3 June 2021

Gramzow L, Theissen G (2010a) A hitchhiker's guide to the MADS world of plants. Genome Biol 11:214
Gramzow L, Theissen G (2013) Phylogenomics of MADS-Box genes in plants-two opposing life styles in one gene family. Biology (basel) 2:1150-1164

Gramzow L, Theissen G (2015) Phylogenomics reveals surprising sets of essential and dispensable clades of MIKC(c)-group MADS-box genes in flowering plants. J Exp Zool B Mol Dev Evol 324:353-362

Grove MD, Spencer GF, Rohwedder WK, Mandava N, Worley JF, Warthen JD, Steffens GL, Flippenanderson JL, Cook JC (1979) Brassinolide, a plant growth-promoting steroid isolated from brassica-napus pollen. Nature 281:216-217

Haas BJ, Papanicolaou A, Yassour M, Grabherr M, Blood PD, Bowden J, Couger MB, Eccles D, Li B, Lieber M, MacManes MD, Ott M, Orvis J, Pochet N, Strozzi F, Weeks N, Westerman R, William T, Dewey CN, Henschel R, Leduc RD, Friedman N, Regev A (2013) De novo transcript sequence reconstruction from RNA-seq using the Trinity platform for reference generation and analysis. Nat Protoc 8:1494-1512

Heijmans K, Morel P, Vandenbussche M (2012) MADS-box genes and floral development: the dark side. J Exp Bot 63:5397-5404

Hill CB, Li C (2016) Genetic architecture of flowering phenology in cereals and opportunities for crop improvement. Front Plant Sci 7:1906

Hugouvieux V, Zubieta C (2018) MADS transcription factors cooperate: complexities of complex formation. J Exp Bot 69:1821-1823

Kater MM, Dreni L, Colombo L (2006) Functional conservation of MADS-box factors controlling floral organ identity in rice and Arabidopsis. J Exp Bot 57:3433-3444

Kim SK, Chang SC, Lee EJ, Chung WS, Kim YS, Hwang S, Lee JS (2000) Involvement of brassinosteroids in the gravitropic response of primary root of maize. Plant Physiol 123:997-1004

Kwantes M, Liebsch D, Verelst W (2012) How MIKC* MADSBox genes originated and evidence for their conserved function throughout the evolution of vascular plant gametophytes. Mol Biol Evol 29:293-302

Lee J, Lee I (2010) Regulation and function of SOC1, a flowering pathway integrator. J Exp Bot 61:2247-2254

Lee H, Suh SS, Park E, Cho E, Ahn JH, Kim SG, Lee JS, Kwon YM, Lee I (2000) The AGAMOUS-LIKE 20 MADS domain protein integrates floral inductive pathways in Arabidopsis. Genes Dev 14:2366-2376

Lee S, Kim J, Han JJ, Han MJ, An G (2004) Functional analyses of the flowering time gene OsMADS50, the putative SUPPRESSOR OF OVEREXPRESSION OF CO 1/AGAMOUS-LIKE 20 (SOC1/ AGL20) ortholog in rice. Plant J 38:754-764

Liu X, Zhu Y, Zhai H, Cai H, Ji W, Luo X, Li J, Bai X (2012) AtP$\mathrm{P} 2 \mathrm{CG} 1$, a protein phosphatase $2 \mathrm{C}$, positively regulates salt tolerance of Arabidopsis in abscisic acid-dependent manner. Biochem Biophys Res Commun 422:710-715

Liu Y, Cui S, Wu F, Yan S, Lin X, Du X, Chong K, Schilling S, Theissen G, Meng Z (2013) Functional conservation of MIKC*-Type MADS box genes in Arabidopsis and rice pollen maturation. Plant Cell 25:1288-1303

Maere S, Heymans K, Kuiper M (2005) BiNGO: a Cytoscape plugin to assess overrepresentation of gene ontology categories in biological networks. Bioinformatics 21:3448-3449

Masiero S, Colombo L, Grini PE, Schnittger A, Kater MM (2011) The emerging importance of type I MADS box transcription factors for plant reproduction. Plant Cell 23:865-872

McCarthy EW, Mohamed A, Litt A (2015) Functional divergence of APETALA1 and FRUITFULL is due to changes in both regulation and coding sequence. Front Plant Sci 6:1076

Mizoguchi T, Wright L, Fujiwara S, Cremer F, Lee K, Onouchi H, Mouradov A, Fowler S, Kamada H, Putterill J, Coupland G (2005) Distinct roles of GIGANTEA in promoting flowering and regulating circadian rhythms in Arabidopsis. Plant Cell 17:2255-2270 
Moon J, Suh SS, Lee H, Choi KR, Hong CB, Paek NC, Kim SG, Lee I (2003) The SOC1 MADS-box gene integrates vernalization and gibberellin signals for flowering in Arabidopsis. Plant J 35:613-623

Munster T, Deleu W, Wingen LU, Ouzunova M, Cacharron J, Faigl W, Werth S, Kim JTT, Saedler H, Theissen G (2002) Maize MADSbox genes galore. Maydica 47:287-301

Mussig C, Shin GH, Altmann T (2003) Brassinosteroids promote root growth in Arabidopsis. Plant Physiol 133:1261-1271

Nelson DE, Repetti PP, Adams TR, Creelman RA, Wu J, Warner DC, Anstrom DC, Bensen RJ, Castiglioni PP, Donnarummo MG, Hinchey BS, Kumimoto RW, Maszle DR, Canales RD, Krolikowski KA, Dotson SB, Gutterson N, Ratcliffe OJ, Heard JE (2007) Plant nuclear factor Y (NF-Y) B subunits confer drought tolerance and lead to improved corn yields on water-limited acres. Proc Natl Acad Sci USA 104:16450-16455

$\mathrm{Ng} \mathrm{M}$, Yanofsky MF (2001) Function and evolution of the plant MADS-box gene family. Nat Rev Genet 2:186-195

Parenicova L, de Folter S, Kieffer M, Horner DS, Favalli C, Busscher J, Cook HE, Ingram RM, Kater MM, Davies B, Angenent GC, Colombo L (2003) Molecular and phylogenetic analyses of the complete MADS-box transcription factor family in Arabidopsis: new openings to the MADS world. Plant Cell 15:1538-1551

Paz MM, Shou HX, Guo ZB, Zhang ZY, Banerjee AK, Wang K (2004) Assessment of conditions affecting Agrobacterium-mediated soybean transformation using the cotyledonary node explant. Euphytica 136:167-179

Pin PA, Benlloch R, Bonnet D, Wremerth-Weich E, Kraft T, Gielen JJL, Nilsson O (2010) An antagonistic pair of ft homologs mediates the control of flowering time in sugar beet. Science 330:1397-1400

Podila GK, Cseke LJ, Sen B, Karnosky DF (2005) Application of aspen mads-box genes to alter reproduction and development in trees. In: Google Patents. Available online at https://patents.google.com/ patent/US20040019933A1/en. Accessed 3 June 2021

Poppenberger B, Fujioka S, Soeno K, George GL, Vaistij FE, Hiranuma S, Seto H, Takatsuto S, Adam G, Yoshida S, Bowles D (2005) The UGT73C5 of Arabidopsis thaliana glucosylates brassinosteroids. Proc Natl Acad Sci USA 102:15253-15258

Ryu CH, Lee S, Cho LH, Kim SL, Lee YS, Choi SC, Jeong HJ, Yi J, Park SJ, Han CD, An G (2009) OsMADS50 and OsMADS56 function antagonistically in regulating long day (LD)-dependent flowering in rice. Plant Cell Environ 32:1412-1427

Schilling S, Pan S, Kennedy A, Melzer R (2018) MADS-box genes and crop domestication: the jack of all traits. J Exp Bot 69:1447-1469

Shannon P, Markiel A, Ozier O, Baliga NS, Wang JT, Ramage D, Amin N, Schwikowski B, Ideker T (2003) Cytoscape: a software environment for integrated models of biomolecular interaction networks. Genome Res 13:2498-2504

Smaczniak C, Immink RG, Angenent GC, Kaufmann K (2012) Developmental and evolutionary diversity of plant MADS-domain factors: insights from recent studies. Development 139:3081-3098

Song G-Q, Chen Q (2018) Overexpression of the MADS-box gene K-domain increases the yield potential of blueberry. Plant Sci 276:10

Song GQ, Walworth A, Zhao DY, Hildebrandt B, Leasia M (2013) Constitutive expression of the K-domain of a Vaccinium corymbosum SOC1-like (VcSOC1-K) MADS-box gene is sufficient to promote flowering in tobacco. Plant Cell Rep 32:1819-1826

Takatsuji H, Kapoor M (2002) Improvement of plant flower type targeting mads box gene. In: Google Patents. Available online at https://patents.google.com/patent/JP2002125684A/ja. Accessed 3 June 2021

Tanabe S, Ashikari M, Fujioka S, Takatsuto S, Yoshida S, Yano M, Yoshimura A, Kitano H, Matsuoka M, Fujisawa Y, Kato H,
Iwasaki Y (2005) A novel cytochrome P450 is implicated in brassinosteroid biosynthesis via the characterization of a rice dwarf mutant, dwarf11, with reduced seed length. Plant Cell 17:776-790

Tapia-Lopez R, Garcia-Ponce B, Dubrovsky JG, Garay-Arroyo A, Perez-Ruiz RV, Kim SH, Acevedo F, Pelaz S, Alvarez-Buylla ER (2008) An AGAMOUS-related MADS-box gene, XAL1 (AGL12), regulates root meristem cell proliferation and flowering transition in Arabidopsis. Plant Physiol 146:1182-1192

Teo ZWN, Zhou W, Shen L (2019) Dissecting the function of MADSBox transcription factors in orchid reproductive development. Front Plant Sci 10:1474

Tester M, Langridge P (2010) Breeding technologies to increase crop production in a changing world. Science 327:818-822

Theissen G, Kim JT, Saedler H (1996) Classification and phylogeny of the MADS-box multigene family suggest defined roles of MADSbox gene subfamilies in the morphological evolution of eukaryotes. J Mol Evol 43:484-516

Theissen G, Becker A, Di Rosa A, Kanno A, Kim JT, Munster T, Winter KU, Saedler H (2000) A short history of MADS-box genes in plants. Plant Mol Biol 42:115-149

Trevaskis B (2018) Developmental pathways are blueprints for designing successful crops. Front Plant Sci 9:745

Verelst W, Saedler H, Munster T (2007) MIKC* MADS-protein complexes bind motifs enriched in the proximal region of late pollenspecific Arabidopsis promoters. Plant Physiol 143:447-460

Walworth AE, Chai B, Song GQ (2016) Transcript profile of flowering regulatory genes in VcFT-overexpressing blueberry plants. PLoS ONE 11:e0156993

Wellmer F, Riechmann JL (2010) Gene networks controlling the initiation of flower development. Trends Genet 26:519-527

Wu J, Lawit SJ, Weers B, Sun J, Mongar N, Van Hemert J, Melo R, Meng X, Rupe M, Clapp J, Haug Collet K, Trecker L, Roesler K, Peddicord L, Thomas J, Hunt J, Zhou W, Hou Z, Wimmer M, Jantes J, Mo H, Liu L, Wang Y, Walker C, Danilevskaya O, Lafitte RH, Schussler JR, Shen B, Habben JE (2019) Overexpression of zmm28 increases maize grain yield in the field. Proc Natl Acad Sci USA 116:23850-23858

Xu P, Chen H, Ying L, Cai W (2016) AtDOF5.4/OBP4, a DOF transcription factor gene that negatively regulates cell cycle progression and cell expansion in Arabidopsis thaliana. Sci Rep 6:27705

Yadava P, Abhishek A, Singh R, Singh I, Kaul T, Pattanayak A, Agrawal PK (2016) Advances in maize transformation technologies and development of transgenic maize. Front Plant Sci 7:1949

Yoo SK, Chung KS, Kim J, Lee JH, Hong SM, Yoo SJ, Yoo SY, Lee JS, Ahn JH (2005) CONSTANS activates SUPPRESSOR OF OVEREXPRESSION OF CONSTANS 1 through FLOWERING LOCUS T to promote flowering in Arabidopsis. Plant Physiol 139:770-778

Yu LH, Miao ZQ, Qi GF, Wu J, Cai XT, Mao JL, Xiang CB (2014) MADS-box transcription factor AGL21 regulates lateral root development and responds to multiple external and physiological signals. Mol Plant 7:1653-1669

Zamboni A, Pierantoni L, De Franceschi P (2008) Total RNA extraction from strawberry tree (Arbutus unedo) and several other woody plants. Iforest 1:122-125

Zhang HM, Forde BG (1998) An Arabidopsis MADS box gene that controls nutrient-induced changes in root architecture. Science 279:407-409

Publisher's Note Springer Nature remains neutral with regard to jurisdictional claims in published maps and institutional affiliations. 